\title{
THE NLRB'S FIRST RULEMAKING: AN EXERCISE IN PRAGMATISM
}

\author{
MARK H. GRUNEWALD*
}

\section{INTRODUCTION}

Despite having been granted both rulemaking and adjudicatory power im its statutory charter more than half a century ago, ${ }^{1}$ the National Labor Relations Board has chosen to formulate pohicy almost exclusively through the process of adjudication. ${ }^{2}$ Decades of critical commentary, ${ }^{3}$

* Professor of Law, Washington and Lee University School of Law. This Article is adapted from a study prepared by the author as a consultant to the Administrative Conference of the United States (ACUS). On June 14, 1991, ACUS adopted a set of recommendations based upon the study. See Facilitating the Use of Rulemaking by the National Labor Relations Board, 56 Fed. Rcg. 33,851-52 (1991) (to be codified at 1 C.F.R. § 305.91-5). The views expressed in this Article, however, are those of the author and do not necessarily reflect those of members of ACUS or its committees except where formal recommendations of ACUS are cited.

1. See National Labor Relations Act (NLRA), Pub. L. No. 74198, 49 Stat. 449, 452 (1935) (codified as amended at 29 U.S.C. $\$ \S 141-197$ (1988)) "The Board shall have authority from time to time to make, amend, and rescind, in the manner prescribed by [the Admimistrative Procedure Act (APA)], such rules and regulations as may be necessary to carry out the provisions of this subchapter." Id. at $\S 156$.

2. The Board did use rulemaking to establish jurisdictional standards for private colleges and universities, see 29 C.F.R. $\S 103.1$ (1991), and for symphony orchestras, see id. §103.2. It also used rulemaking in deciding not to assert jurisdiction over the horse racing industry. See id. $\S 103.3$; see also 2 The Developing Labor Law: The Board, the Courts, and the National Labor RELATIONS ACT 1631 nn. 21416 (Charles J. Morris ed., 2d ed. 1983).

3. See, e.g., Merton C. Bernstein, The NLRB's Adjudication-Rule Making Dilemma Under the Administrative Procedure Act, 79 YALE L.J. 571 (1970) (suggesting that the Board make greater use of its ruleinaking powers); Samuel Estreicher, Policy Oscillation at the Labor Board: A Plea for Rulemaking, 37 ADMIN. L. REv. 163, 181 (1985) (arguing that the use of rulemaking for policy reversals would "improve the quality of the [Board]'s decisions, its success rate in the courts, and, ultimately, its institutional standing"); Kenneth Kahn, The NLRB and Higher Education: The Failure of Policymaking Through Adjudication, 21 UCLA L. REv. 63, 167-75 (1973) (claiming that the Board's use of adjudication in the field of unit determinations for college and university faculty has produced bad case law and may lead to results not intended by the Board); Charles J. Morris, The NLRB in the Dog House-Can an Old Board Learn New Tricks?, 24 SAN Diego L. REv. 9 (1987) (criticizing the Board's record on enforcement of core enıployee protection provisions); Cornelius J. Peck, The Atrophied Rule-Making Powers of the National Labor Relations Board, 70 YALE L.J. 729, 756 (1961) [hereinafter Peck, Rule-Making Powers] (condemning the Board's reliance on ad hoc policymaking as being harmful to both the Board's own program and general public and private interests); Cornelius J. Peck, $A$ Critique of the National Labor Relations Board's Performance in Policy Formulation: Adjudication and Rule-Making, 117 U. PA. L. REv. 254 (1968) (describing the detrimental aspects of the Board's adherence to adjudication); David L. Shapiro, The Choice of Rulemaking or Adjudication in the Development of Administrative Policy, 78 HARV. L. REv. 921, 922 (1965) (evaluating the advantages of both rulenaking and adjudication and presenting some benefits to greater reliance on rulemaking); Carl S. Silverman, The Case for the National Labor 
frequent prodding from reviewing courts, ${ }^{4}$ and legislative proposals for mandatory rulemaking ${ }^{5}$ had no apparent effect on the Board's commitment to adjudication as its single method of policy formulation. Even as rulennaking echipsed adjudication as the preferred method for policymaking among other major federal agencies, ${ }^{6}$ the Board steadfastly clung to the quasi-judicial approach, almost as a necessary tenet in the regulation of labor-inanagement relations. It seemed the Board was one federal agency that would never be persuaded of the virtues of notice and comment ruleinaking.

Then, on July 2, 1987, these startling words appeared in the Federal Register:

In order to facilitate the election process, the National Labor Relations Board proposes to amend its rules to include a new provision specifying which bargaining units will be found appropriate in various types of health care facilities. The Board has resolved to utilize notice-andcomment rulemaking rather than be presented with continuing lengthy and costly hitigation over the issue of appropriate bargaining units in each case. Interested parties may submit oral testimony in connection with the proposed rules. ${ }^{7}$

Relations Board's Use of Rulemaking in Asserting Jurisdiction, 25 LAB. L.J. 607 (1974) (suggesting that the Board could better effectuate the purposes and policies of the NLRA by rulemaking rather than by adjudication); Berton B. Subrin, Conserving Energy at the Labor Board: The Case for Making Rules on Collective Bargaining Units, 32 LAB. L.J. 105 (1981) (concluding that the Board's policy of determining the appropriate bargaining unit by case-by-case adjudication is inefficient and creates harmful uncertainties that could be eliminated by rulemaking). But see Robert L. Willmore, Note, NLRB Rulemaking: Political Reality Versus Procedural Faimess, 89 YALE L.J. 982 (1980) (arguing that Board's reliance on adjudication minimizes congressional and judicial intervention and thus gives the Board needed flexibility in developing policy).

4. See, eg., NLRB v. Res-Care, Inc., 705 F.2d 1461, 1466 (7th Cir. 1983) (asserting that the Board's strict adherence to adjudication in applying section $2(11)$ of the NLRA has made it vulnerable to charges of opportunism, and concluding that the Board would be entitled to more judicial deference in its interpretation "if it had awakened its dornant rulemaking powers for the purpose of particularizing the apphication of section 2(11) to the medical field"); NLRB v. Majestic Weaving Co., 355 F.2d 854, 860 (2d Cir. 1960) (noting the "imcreasing expression of regret" over the Board's failure to incrcase its use of rulemaking); see also NLRB v. Wyman-Gordon Co., 394 U.S. 759, 764 (1969) (stating that where the Board purports to make a general rule it cannot use adjudication to avoid comphance with the provisions of the APA that govern rulemaking).

5. Provisions of the proposed Labor Law Reform Act of 1978, S. 2467, 95th Cong., 2d Sess., 124 CONG. REC. 1505, would have required the Board to make greater use of rulemaking in some areas, most notably in delineating "plainly appropriate units" for purposes of collective bargaining. See S. REP. No. 628, 95th Cong., 2d Sess. 18-20 (1978).

6. See Bernard Schwartz, Administrative Law 167 (3d ed. 1991).

7. Collective-Bargaining Units in the Health Care Industry, 52 Fed. Reg. 25,142 (1987) [hereinafter NPR I] (notice of proposed rulemaking and notice of hearing). 
Almost two years later the Board publislied a final rule governing bargaining unit determinations in health care facilities. ${ }^{8}$ The Board's institutional resolve against substantive rulemaking appeared to lave collapsed, and it was possible to imagine wide-ranging and vigorous use of this previously dormant policymaking device in the labor relations area.

This Article documents the Board's first major use of rulemaking, evaluates its significance, and identifies aspects of the experience that suggest a need for possible reform. ${ }^{9}$ The cliallenge of the exercise lies in balancing an understanding of the umqueness of the pohicy problem that triggered the rulemaking with an appreciation of the richness of this experience as a gride to possible broader use of rulemaking by the Board. Part I reviews briefly the law and policy governing agency clioice between rulemaking and adjudication in the regulatory process and the imphications of that choice for the Board. Part II chronicles the developinents in unit determinations under the Health Care Amendments of 1974 that led to the Board's decision to use rulemaking. Part III discusses the dynamics of the rulemaking process and the evolution of the rule itself. Part IV exannines the litigation sparked by the promulgation of the final rule and the impact of that litigation on the Board's activities. Finally, Part V considers the broader implications of this novel undertaking by the Board, atteinpts to evaluate its relative success in accoinphshing its goals, and nakes recommendations that might improve future ruleinaking proceedings. The Article concludes tliat, despite the promise that ruleinaking holds for the regulation of labor

8. Appropriate Bargaining Units in the Health Care Industry, 29 C.F.R. $\S 103.30$ (1991). The rule, along with background and rationale, was originally published as Collective-Bargaining Units in the Health Care Industry, 54 Fed. Reg. 16,336 (1989) [hereinafter Final Rule]. Subsequent references to the Final Rule will therefore be made to the Federal Register.

9. As part of the study, the author conducted in-person and telephone interviews with agency officials and members of the labor-inanageinent bar. [hereinafter Interviews]. The author's description of certain aspects of the rulemaking is drawn froin these interviews collectively, but no part of the description is imtended to reflect the views of any individual interviewee.

The following persons were interviewed:

James M. Stephens, Chairman, National Labor Relatious Board; Mary Miller Cracraft, Member, National Labor Relations Board; Dennis M. Devaney, Member, National Labor Relations Board; Clifford R. Oviatt, Jr., Member, National Labor Relations Board; John E. Higgins, Solicitor, National Labor Relations Board; John C. Truesdale, Executive Secretary, National Labor Relations Board; Linda Sher, Assistant General Couusel, National Labor Relations Board; Bcrton Subrin, Director, Office of Representation Appeals; Sandra Elhigers, Attorney, Office of Representation Appeals; Bernard Ries, Admimistrative Law Judge, National Labor Relations Board; Thomas P. Burke, Co-Chair, Committce on National Labor Relations Board Practice and Procedure, American Bar Association Section on Labor Law; Lawrence B. Miller, Co-Chair, Committee on National Labor Relations Board Practice and Procedure, American Bar Association Section on Labor Law; and David A. Grant, Chair, Labor and Employment Law Committee, American Bar Association Section on Administrative Law and Regulatory Practice. 
relations, the prospect for further use of rulemaking by the Board depends largely on its evaluation of the costs and benefits of this undertakmg as the rule is implemented.

\section{The Choice Between Rulemaking and Adjudication}

\section{A. Agency Discretion to Choose}

The Board's historic resistance to rulernaking as an instrument of pohicyinaking forms an important part of the inore general issue of the degree to which administrative agencies have the discretion to choose between rulemaking and adjudication and the legal and policy consequences of that choice. ${ }^{10}$ As early as 1947, the need for agency discretion in the choice between the two modes of procedure was acknowledged by the Supreme Court in SEC v. Chenery Corp. (Chenery II): ${ }^{11}$

Since the [Securities and Exchange] Commission, unlike a court, does have the ability to make new law prospectively through the exercise of its rule-making powers, it has less reason to rely upon ad hoc adjudication to formulate new standards of conduct within the framework of the Holding Company Act. The function of filling in the interstices of the Act should be performed, as much as possible, through this quasilegislative promulgation of rules to be applied in the future. But any rigid requirement to that effect would make the administrative process inflexible and incapable of dealing with many of the specialized problems which arise. Not every principle essential to the effective administration of a statute can or should be cast immiediately into the mold of a general rule. Some principles must await their own development, while others must be adjusted to meet particular, unforeseeable situations. In performing its important functions in these respects, therefore, an administrative agency must be equipped to act either by general rule or by individual order. To insist upon one form of action to the exclusion of the other is to exalt forin over necessity. ${ }^{12}$

By the time of Chenery II, the Board had, in its first twelve years of operation, established a firm commitınent to adjudication. Durmg this period, the substance of the Board's policynaking, the agency structure for decisionmaking, and the scope of judicial review of its decisions were the primary subjects of controversy. ${ }^{13}$ The Board's exclusive reliance on adjudication was of hittle interest. The Taft-Hartley Act of $1947^{14}$ reaffirmed the Board's rulemaking authority and made such action subject to

10. See Richard K. Berg, Re-examining Policy Procedures: The Choice Between Rulemaking and Adjudication, 38 ADMIN. L. REv. 149 (1986); Arthur E. Bonfield, State Administrative Policy Formulation and the Choice of Lawmaking Methodology, 42 ADMIN. L. REv. 121 (1990).

11. 332 U.S. 194 (1947).

12. Id. at 202 (citation omitted).

13. The 1947 Taft-Hartley amendments to the NLRA addressed each of these matters, in addition to establishing curbs on union power. See H.R. REP. No. 240, 80th Cong., 1st Sess. 3-6 (1947).

14. 29 U.S.C. $\S \S 141-197$ (1988). 
the Administrative Procedure Act (APA), ${ }^{15}$ but apparently this amendment was neither imtended nor understood to encourage the Board to make greater use of that authority. ${ }^{16}$

Over the next two deeades, the use of rulenaking in inajor federal agencies grew, and a body of commentary and judicial opinion developed encouraging and approving this move. ${ }^{17}$ In turn, the pohicy considerations underlying the decision in Chenery II came into sharper focus, and ultimately the issue shifted to the question of limits on agency discretion to choose between modes of procedure. The power of agencies to resolve recurring issues in adjudicatory hearings by establishing general principles under their rulemaking authority was broadly asserted and approved. ${ }^{18}$ The gains in administrative efficiency achieved through the use of general rules were frequently seen by the courts' as outweighing the previously assumed superiority of policy incrementally evolved through case-by-case consideration. ${ }^{19}$ At the same time, rulemaking was acknowledged to offer a broader opportumity for public participation and more ineaningful notice to affected parties of regulatory standards. 20 These efficiency and fairness arguments supporting agency choice of ruleinaking generally carried the day. ${ }^{21}$ The controversy centered instead on the choice of adjudication. Here, the Board's long-standing rehance on adjudication tested the limits of the discretion conferred by Chenery II.

15. Id. § 156 .

16. The purpose of the amendment appears to have been to make clear that the Board's exercise of its rulemaking authority would have to conform to the procedural requirements of the thenrecently enacted APA. See H.R. CoNf. REP. No. 510, 80th Cong., 1st Sess. 38 (1947).

17. See Richard J. Pierce et al., Administrative Law and Process 34-36 (1985); SCHWARTZ, supra note 6 , at 170-71.

18. See Umited States v. Storer Broadcasting Co., 351 U.S. 192, $202-06$ (1956) (upholding authority of FCC to promulgate and to enforce rule denying additional licenses to parties already holding five or more television stations despite language in Communications Act of 1934 that required a "full hearing" before denials of such licenses); see also WBEN, Inc. v. United States, 396 F.2d 601, 617-22 (2d Cir.) (rejecting argument that provisions of Communications Act of 1934 that require evidentiary hearings before license modification prevent $\mathrm{FCC}$ from promulgating rule establishing a new system for pre-sunrise operations by certain classes of AM radio stations), cert. denied, 393 U.S. 914 (1968); American Airlines, Inc., v. Civil Aeronautics Bd., 359 F.2d 624, $628-33$ (D.C. Cir. 1966) (upholding Civil Aeronautics Board use of rulenaking to allow only all-cargo carriers to provide "block space service" based on agency need for the flexibihty rulemaking provides, and concluding that the fairness of the proceeding would not have been enhanced by requiring adjudicatory procedures).

19. See SCHWARTZ, supra note 6 , at 170-71.

20. See Pierce, supra note 17, at 322-27.

21. See, e.g., National Petroleum Refiners Ass'n v. FTC, 482 F.2d 672 (D.C. Cir. 1973) (upholding FTC authority to engage in substantive trade regulation rulemaking on grounds of efficiency and fairness despite lack of express authorization for mlemaking in Trade Commission Act). 
The Board's refusal to use its rulemaking authority for substantive matters drew criticism in 1958 from the American Bar Association's Labor Law Section. The Section recommended that the Board reconsider its position that the promulgation of certain of its most rule-like policies did not require compliance with the rulemaking procedures of the APA. 22 A few years later, in a seminal work on the subject, Professor Cornelius Peck broadly cliallenged the Board's position that its work inlerently demanded an adjudicatory approach, and urged that the Board undertake rulemaking for a portion of its work. ${ }^{23}$ Over the next several years, a series of actions at the Board culminated in a Supreme Court decision specifically addressing the question of whether a policy announced in the course of an adjudication was in fact a "rule" that required compliance witl the APA for its proinulgation.

In $N L R B$ v. Wyman-Gordon Co. ${ }^{24}$ a divided Court uplield the application of a rule-like policy announced (altlough not applied) in one adjudication to a different party in a subsequent adjudication. A majority of the Court, lowever, througl several separate opinions, ${ }^{25}$ expressed disapproval of the Board's disregard of the APA procedures for rulemaking, particularly in liglit of the Board's decision in the original adjudication to apply the policy only prospectively. Wyman-Gordon was generally interpreted as signaling the Court's intention to scrutinize inore closely the Board's avoidance of the rulemaking process. ${ }^{26}$ The unusual division of opinions in the case, ${ }^{27}$ lowever, left unclear low inore

22. See Report of the Committee on National Labor Relations Practice and Procedure, 1958 A.B.A. SEC. LAB. REL. L. 110. The recommendation, approved by the House of Delegates, provided that "[t]lhe Board sloould recousider its views that its decisional policies on such matters as jurisdictional standards and contract-bar rules do not come within the rule-making requirements of the Administrative Procedure Act." Id. at 121.

23. Peck, Rule-Making Powers, supra note 3.

24. 394 U.S. 759 (1969).

25. See id. at 76466 (plurality opimion) (Fortas, J., jomed by Warren, C.J., Stewart, J., and White, J.); 'id. at 775-80 (Douglas, J., dissenting); id. at 780-81 (Harlan, J., dissenting).

26. See Bernstem, supra note 3, at 573-74.

27. Justice Fortas, in an opinion joined by threc other Justices, concluded that the Board had promulgated a "rule" in Excelsior Underwear without complying with the rulemaking procedures of the APA, but the application of the rule to Wyman-Gordon was lawful because it occurred in an separate adjudication directed specifically to Wyinan-Gordon. Justice Black, in an opimion joined by two others, concluded the so-called "rule" was the valid product of an the adjudication of the Excelsior Underwear case and within the scope of agency discretion to formulate policy through eitler adjudication or rulemaking. In a separate dissent, Justice Douglas concluded that the Excelsior "rule" vas clearly intended by the Board to have general applicability in future cases and that to formulate it in an adjudication would violate the letter and purpose of the APA. Justice Harlan concluded that the Board's decision not to apply the Excelsior "rule" to the Excelsior company itself made the policy one of only "future effect" thereby falling within the APA's definition of a rule. Thus, of the nime Justices participating, ouly Douglas and Harlan would have denied the Board the power to apply the "rule" in future cases even though they and four other Justices (Fortas and the 
intensive scrutiny might be accoinphished consistent with the discretion accorded by Chenery $I I .^{28}$

Less than five years after Wyman-Gordon, the Court granted certiorari in a case in which the Court of Appeals for the Second Circuit had sought to apply the admonitions of Wyman-Gordon in reviewing a new Board policy formulated in an adjudication. ${ }^{29}$ Rebuffing the panel's effort, the Supreine Court in $N L R B$ v. Bell Aerospace Co. ${ }^{30}$ unanimously reaffirmed the application of Chenery II and sustained the Board's apphcation of the "managerial einployee" exemption to certain industrial buyers. ${ }^{31}$ The Court observed:

The views expressed in Chenery II and Wyman-Gordon make plain that the Board is not precluded froin announcing new principles in an adjudicative proceeding and that the choice between ruleınaking and adjudication hes in the first instance within the Board's discretion. Although there inay be situations where the Board's rehance on adjudication would amount to an abuse of discretion or a violation of the Act, nothing in the present case would justify such a conclusion. Indeed, there is ample indication that adjudication is especially appropriate in the instant context.... [D]uties of buyers vary widely depending on the company or industry. It is doubtful whether any generalized standard could be framed which would have more than inarginal utility. The Board thus has reason to proceed with caution, developing its standards in a case-by-case manner with attention to the specific character of the buyers' authority and duties in each company. The Board's judgment that adjudication best serves this purpose is entitled to great weight. ${ }^{32}$

three Justices concurring with him) found the rule to have been improperly promulgated because of the Board's failure to comply with APA rulemaking procedures.

28. See Bernstein, supra note 3 , at 598 .

29. Bell Aerospace Co. v. NLRB, 475 F.2d 485 (2d Cir. 1973). The new policy reformulated the Board's classification and treatment of "managerial employees." The Court of Appeals concluded that, because a majority of Justices in Wyman-Gordon indieated that changes in rules of general apphieation can be effected only through compliance with the rulemaking provisions of the APA, the Board's use of adjudieation to modify its classification of "managerial einployees" was invalid. See id. at $495-96$.

30. 416 U.S. 267 (1974).

31. See id. at 290-95. However, the Court rejected the Board's attempt to apply a new interpretation of the Taft-Hartley Act, one that allowed soine "managerial einployees" to be covered by the Act, to the adjudication before it. The case was therefore remanded to the Board so that it could apply the proper legal standard. See id. at 289-90.

32. Id. at 294. The Court continued by distinguishing the Bell Aerospace circumstances from those cases in which concerus about retroactive effect would be greater:

The possible reliance of industry on the Board's past decision witl respect to buyers does not require a different result. It has not been shown that the adverse consequences ensuing froin such reliance are so substantial that the Board should be precluded from reconsidering the issue in an adjudicative proceeding. Furthermore, this is not a case in whicls soine new liability is sought to be inposed on individuals for past actions which were taken in Id. good-faith rehance on Board pronounceinents. Nor are fines or damages involved here. 
Thus, Wyman-Gordon and Bell Aerospace only modestly constrain the discretion of the Board to choose between rulemaking and adjudication. Although either liarsh retroactive effects of a new policy formulated and applied in an adjudication, or the unseemliness of a new policy announced but not applied in a particular adjudication may trigger closer judicial scrutiny, the Court lias remained largely faithful to the Chenery $I I$ view that flexibility in the clioice of mode of procedure is an essential attribute of administration.

\section{B. Practical Considerations in the Choice of Mode of Procedure}

Although Wyman-Gordon and Bell Aerospace address the formal limits on the Board's exercise of discretion in the choice of procedural mode, the ongoing controversy lias more concerned the practical imphcations of the Board's preference for adjudication in the accoinplishment of its regulatory imission. Broadly stated, there are five considerations: (1) the form and nature of the data upon which Board policy is based; (2) the openness of the policymaking process; (3) the clarity of Board policy; (4) the stability of Board policy; and (5) the efficiency of the policy enforcement process. ${ }^{33}$ Each of these concerns is independently quite coinplex, and that complexity is compounded by the relationships between them. For present purposes, a synthesis (rather than an elaboration) of them is likely to be inost helpful.

The policy product of Board adjudications generally takes one of two forms. First, there are cases in the common law inode that mvolve application of established policy to particular facts. ${ }^{34}$ Cases of this kind, because of subtle changes over time, represent an evolutionary, incremental form of policymaking. Second, there are cases in which the Board, acting more in a legislative inode, uses the immediate controversy snnply as a vehicle to announce more drastic policy changes without mucli regard for the particular facts. ${ }^{35}$ When proceeding in the legislative mode, the essence of the policy product is indistinguishable from the product of a rulemaking. The policy formulated may be an extremely

33. See Estriecher, supra note 3, at 171-77; Morris, supra note 3, at 27-42; Peck, Rule-Making Powers, supra note 3 , at $752-61$.

34. This class of cases is well illustrated by the fact-intensive unfair labor practice adjudications in which the Board determines whether particular bargaining meets the "good faith" standard of section 8(d) of the NLRA. E.g., NLRB v. A-1 King Size Sandwich, Inc., 723 F.2d 872 (11th Cir.), cert. denied, 469 U.S. 1035 (1984).

35. This class of cases is well illustrated by Excelsior Underwear, Inc., 156 N.L.R.B. 1236 (1966), the adjudication at issue in Wyman-Gordon. Excelsior established the policy that seven days after an election is directed or consented to the employer must provide to the Board for transmittal to the union a list of the names and addresses of employees who will be eligible to vote in the election. Id. 
precise rule that requires only mechanical application, or it may be a vague, open-ended rule that sets out only the general contours by which future cases are to be decided. The particularity of the policy in one instance or the generality of it im another may liave important enforcement implications, but both kinds of policy formulated in this fashion share an important feature. It is formulated exclusively froin argument and evidence that the parties to the proceeding offer (evaluated in liglit of the Board's expertise). Consequently, it formally lacks as a basis the breadth of data tliat ruleinaking submissions can provide, and even the data upon which it is based is presented by a limited number of participants. The seriousness of these shortcomings is then a critical issue in evaluating the choice not to use notice and comment rulemaking in cases taking this form. Cases taking the traditional cominon law form raise no such questions and would arise even where true rules requiring more than mechanical application were in place.

The breadth and sources of the data for policynaking are thus both obvious and fundanental concerns. Concern with policy clarity and stability is more subtle and perhaps peripheral. Because the line between the two forms of adjudication described above is not always clear, important policy clianges can be lost (or hidden) in the reasoning process of adjudication. Similarly, the opportumity exists for unanticipated policy shifts, unanticipated both in the sense of limited notice of the prospect of change and in the volatility of existing pohicy majorities in the face of changes in Board membership. Rulemaking thus provides clarity, not in the sense of the specificity of policy (which may vary from rule to rule), but in the identification of a decision as a pohcy choice. It also provides stability, not in the sense of uncliangeable policy, but in policy that can not be changed without a process focused on the policy clioice.

Finally, the pohicymaking procedure can affect the efficiency of the enforceinent process. To the extent that a single ruleinaking can lay to rest important policy issues that would otherwise require a long series of adjudications, enforceinent is advanced. Moreover, in rulemaking, the pohicymaking agenda can be set internally witl a view toward enforcement needs, rather than externally in the form of cases that parties choose to press. Nevertheless, much of the value of rulemaking remains dependent upon time expended, resources consuined, and, most importantly, the form of the ruleinaking product.

\section{The Board's Choice of Rulemaking: Health Care BARGAINING UNITS}

The Board's choice of health care bargaining umits for its first major ruleinaking is inextricably intertwined with the agency's struggle witl 
that subject for nearly fifteen years after the passage of the Health Care Amendments to the NLRA im $1974 .{ }^{36}$ It is therefore necessary to consider preliminarily, but briefly, the background of the substantive issue that the Board chose to deal with through rulemaking.

\section{A. The 1974 Health Care Amendments to the National Labor Relations Act}

In the early years of the National Labor Relations Act (NLRA), the Board asserted jurisdiction over non-profit hospitals. ${ }^{37}$ The Taft-Hartley amendments of 1947 reversed that pohicy by excluding such imstitutions from the definition of "employer."38 Thereafter the Board equalized the . status of all hospitals under the NLRA by refusing to assert jurisdiction over proprietary hospitals as well. ${ }^{39}$ Then, in 1967, the Board reversed course and asserted jurisdiction over proprietary hospitals, ${ }^{40}$ leaving only non-profit hospitals statutorily excluded. The Health Care Amendments to the Act in 1974 finally settled the question of coverage for all hospitals by repealing the statutory exclusion for non-profit hospitals. ${ }^{41}$ Thus, after 1974, health care institutions beeame subject to Board jurisdiction without regard to their status as proprietary or non-profit.

In addition to resolving the coverage issue, the 1974 amendments included substantive provisions that govern labor-management relations in the health care fields specifically. A provision that was proposed, but not enacted, would have limited the Board to finding only four appropriate bargaining units in the health industry: (1) a unit of all professionals; (2) a unit of all technical employees; (3) a unit of all clerical employees; and (4) a unit of all mamtenance and service employees. ${ }^{42}$ This proposal was grounded in the view, propounded by health care employers, that Board unit determinations based upon a more refined analysis of the

36. Act of July 26, 1974, Pub. L. No. 93-360, 88 Stat. 395 (codified as amended at 29 U.S.C. $\S \S 151-169$ (1988)).

37. See Central Dispensary \& Emergency Hosp., 50 N.L.R.B. 393 (1943), aff'd, 145 F.2d 852 (D.C. Cir. 1944), cert. denied, 324 U.S. 847 (1945).

38. The legislation amended the Act's definition of employer to exclude "any corporation or association operating a hospital, if no part of the net earnings inures to the benefit of any private shareholder or individual." Labor Management Relations (Taft-Hartley) Act, ch. 120, sec. 101, $\S 2(2), 61$ Stat. 136, 137 (1947) (current version at 29 U.S.C. $\S 152(2)$ (1988)). See generally JoHN E. ABodeely et al., The NLRB aNd the APPRopriate Bargaining UNIT 249-50 (rev. ed. 1981) (discussing the factors considered by the Board, prior to the 1974 amendment, to determine the appropriate unit for collective bargaining).

39. See Flatbush Gen. Hosp., 126 N.L.R.B. 144, 145-46 (1960).

40. See Butte Medical Properties, 168 N.L.R.B. 266, 268 (1967).

41. See Act of July 26, 1974, Pub. L. No. 93-360, 88 Stat. 395,395 (codified at 29 U.S.C. $§ 152$ (1988)).

42. See S. 2292, 93d Cong., 1st Sess. 119 Cong. Rec. 26792 (1973). 
myriad occupational categories in the typical hospital would create an unacceptable degree of fragmentation for purposes of collective bargainmg. ${ }^{43}$ Under this view, smaller units would raise health care costs and jeopardize patient care by increasing the number and scope of strikes, stimulating jurisdictional disputes, and pronoting whipsaw tactics in bargaining. 44

Despite vigorous lobbying by health care enployers (led by the American Hospital Association (AHA)), this proposal was rejected, leaving the Act's provisions on bargaining unit determinations unchanged. Nevertheless, both the Senate and House expressed solicitude for the en1ployers' concern by including a statenient in their respective committee reports that "[d]ue consideration should be given by the Board to preventing proliferation of bargaining units in the health care industry." 45 For the next fifteen years, the health care employers, unions, and the Board devoted significant resources to reconciling the Board's traditional discretion in the umit determination area with this piece of legislative history. ${ }^{46}$

\section{B. The Nonproliferation Issue and Unit Politics}

Unit proliferation became a troublesoine issue in health care cases not only because industry concerns in the legislative process were addressed only obliquely through an agreed statenient in the legislative history, but also because unit determinations generally involve high stakes. Put most simply, larger, more heterogeneous units are harder to organize than sinaller, inore hoinogeneous ones. Representation elections are frequently won and lost on the basis of the Board's unit determination. ${ }^{47}$ Even after a union election victory, labor relations are often profoundly affected by the eniployee configurations established at the unit determination stage. 48

It is not surprising, then, that hospitals pressed the view that the legislative history statenent, which became known as the "congressional adinonition," 49 was intended as a direction to the Board to confine itself, to the greatest extent practical, to the four units specified in the failed

43. See ABODEely, supra note 38 , at 246-47.

44. See Coverage of Nonprofit Hospitals Under National Labor Relations Act, 1973: Hearing on S. 794 and S. 2292 Before the Subcomm. on Labor of the Senate Comm. on Labor and Public Welfare, 93d Cong., 1st Sess. 198-200 (1973) (testimony of the California Hospital Association).

45. S. Rep. No. 7667, 93d Cong., 2d Sess. 5 (1974); accord H.R. REP. No. 1031, 93d Cong., 2d Sess. 7 (1974); S. CoNF. REP. No. 988, 93d Cong., 2d Sess. 7 (1974).

46. See ABODEELY, supra note 38 , at 249-76.

47. Id. at 339.

48. See id.

49. NLRB v. St. Francis Hosp. of Lynwood, 601 F.2d 404, 414 (9th Cir. 1979). 
legislative provision. Nor was it surprising that health care unions strenuously resisted this construction of the legislative events, urging instead that the Board pursue its traditional "community of interest" analysis in naking unit determinations. This division of views led to highly contentious hitigation before the Board and the courts of appeals that, over time, produced policy conflicts within the Board and divisions in the circuits. The history of this litigation is lengthy and coinplex, ${ }^{50}$ but its essence can be captured by considering the Board's general approach to unit questions along with a few illustrations specific to the lealtl care industry.

Section 9(a) of the NLRA provides that representation of employees for purposes of collective bargaining shall occur "in a unit appropriate for such purposes." 51 Section 9(b) provides that the Board "shall decide in each case whether, in order to assure to einployees the fullest freedom in exercising tlie rights guaranteed by [the Act], the unit appropriate for purposes of collective bargaining shall be tlie employer unit, craft unit, plant unit, or subdivision thereof." 52 The Supreme Court lias held that these broad directives vest the Board witl wide discretion im determining when a unit is appropriate. ${ }^{53}$

In acting on an election petition, the Board traditionally decides whetler the petitioned-for employee group shares a sufficient "community of interest" to warrant desiguating those employees an appropriate unit. ${ }^{54}$ "Community of interest" is a standard that takes account of a number of factors:

(1) similarity in the scale and manner of determining earnings; (2) similarity in employment benefits, hours of work, and other terms and conditions of employment; (3) similarity in the kind of work performed; (4) similarity in the qualifications, skills, and training of the einployees; (5) frequency of contact or interchange among employees;

50. See ABodeely, supra note 38, at 250-90; Kathleen A. Curran, Note, The National Labor Relations Board's Proposed Rules on Health Care Bargaining Units, 76 VA. L. REV. 115, 127-44 (1990).

51. 29 U.S.C. $\S 159$ (a) (1988).

52. Id. $\S 159(\mathrm{~b})$.

53. In NLRB v. Hearst Publications, 332 U.S. 111 (1944), the Supreme Court wrote: Wide variations in the forms of employee self-organization and the complexities of modern mdustrial organization make difficult the use of inflexible rules as the test of an appropriate umit. Congress was informed of the need for shaping the unit to the particular case and accordingly gave the Board wide discretion in the matter.

Id. at 134.

54. Under the NLRA, the unit need be only an appropriate unit, not the appropriate uirit. See 29 U.S.C. $\$ 159$ (a) (1988). Thus, categories of employees may be grouped a number of different ways and still satisfy the appropriateness requirement.

The immediate consequence of determining a unit to be appropriate is that the employees within that unit will be the constituency in the representation election; the ultimate consequence is that if the union prevails in the election, those employees will constitute a separate unit for purposes of collective bargaining. 
(6) geographic proximity; (7) continuity or integration of production processes; (8) common supervision and determination of labor relations policy; (9) relationship to the administrative organization of the employer; (10) history of collective bargaining; (11) desires of the affected einployees; and (12) extent of union organization. ${ }^{55}$

Application of the standard is formally based on detailed and intensive factual analysis, but the complexity of the standard itself and the subtlety of some of its" components tend to broaden, rather than constrain, the Board's exercise of discretion. These characteristics also invite protracted evidentiary presentations and fine legal distinctions. The liearing process (and, in turn, the decisional product) is often prolix. ${ }^{56}$ Nevertheless, over time, the body of decisions reflects coinmon approaclies to recurring issues that provide a substantial degree of predictability in unit determinations.

In the healtl care setting, the Board's treatment of two categories of einployees-registered nurses and skilled maintenance workers-illustrates the unit problem well. Shortly after the Healtlı Care Amendinents becaine effective, the Board held that a unit consisting entirely of registered nurses (RNs) was appropriate given the RNs' work roles and professional separateness. ${ }^{57}$ This decision and similar ones ${ }^{58}$ finding separate units for RNs to be appropriate, rather than including thein in "all professional" units, provoked judicial disapproval on the ground that the Board had adopted a per se rule for RNs. This approach was thought to be particularly objectionable in light of the "congressional admonition" against unit proliferation. In NLRB v. St. Francis Hospital of Lynwood, 59 the Court of Appeals for the Ninth Circuit concluded:

[This line of] precedent contravenes that congressional admorition by establishing an irrebuttable presunption in favor of certain units.

55. Robert A. Gorman, LABOR LAW: Unionization and Collective Bargaining 69 (1976); see also NLRB v. Purnell's Pride, Inc., 609 F.2d 1153, 1156 (5th Cir. 1980) (listing "bargaining history, operational integration, geographic proximity, common supervision, sirnilarity in job function, and degree of employee interchange" as relevant factors in determining "community of interest").

56. See, e.g., Subrim, supra note 3:

In ascertaining the community of interest, the Board for over forty years has looked at such factors as the nature of the work, skills and compensation of the employees, supervision, functional coherence, and geographical separation. Board volumes are replete with decisions containing lengthy narratives as to whether the plant inanager can hire or fire or schedule or grant overtime, which parking lot or restrooms various groups use, how many employees transferred into the unit from elsewhere in the plant, or which einployees wear common uniforms.

Id. at 105-06 (footnote omitted).

57. See Mercy Hosps. of Sacramento, Inc., 217 N.L.R.B. 765, 766-68 (1975).

58. E.g., Ralph K. Davies Medical Ctr., 256 N.L.R.B. 1113 (1981); Brookwood Hosp., 252 N.L.R.B. 748 (1980); Lancaster Osteopathic Hosp. Ass'n 246 N.L.R.B. 600 (1979); MorristownHamblem Hosp. Ass'n, 226 N.L.R.B. 76 (1976).

59. 601 F.2d 404 (9th Cir. 1979). 
While Congress did not pass S.2292 which would have set up a uniform four unit for all non-profit hospitals, that failure does not sanction the Boards's establishment of its own more extensive five-unit standard . . . 60

Thereafter, the Board made explicit that its approach to $\mathrm{RN}$ petitions was to apply its traditional "community of interest" standard on a caseby-case basis. ${ }^{61}$ The Board also asserted that its body of cases, predominantly finding separate $\mathrm{RN}$ units appropriate, was both consistent with that standard and reflected sensitivity to the expressed congressional concern with unit proliferation. ${ }^{62}$

Despite the Board's effort to fit health care unit determinations into its community of interest approach, the Ninth Circuit's assertion in $S t$. Francis Hospital of Lynwood that the "congressional adinonition" required a "disparity of interest" approach gained growing judicial acceptance. ${ }^{63}$ Under this approach, only a deinonstration that the interests of a particular einployee group (such as RNs) were disparate from a larger grouping (such as "all professionals") would justify finding a separate unit appropriate. ${ }^{64}$ In response, the Board made still another effort to satisfy the courts that it was proceeding consistently with congressional intent. Acting on a petition for a separate unit of skilled maintenance workers in St. Francis Hospital $I,{ }^{65}$ the Board identified seven potentially appropriate units: physicians, registered nurses, other professionals, technical einployees, business office clericals, service and maintenance einployees, and skilled maintenance employees. ${ }^{66}$ Only if a petition sought one of these units would the Board proceed to the community of interest analysis. This approach would thus respect non-proliferation concerns by limiting the nunber of possible units to seven, while at the same time preserving the community of interest standard. Before the $S t$. Francis $I$ approach had been subjected to judicial review, however, the Board shifted course and, in St. Francis Hospital $I I, 67$ adopted essentially

60. Id. at 414.

61. See Newton-Wellesley Hosp., 250 N.L.R.B. 409, 411-15 (1980).

62. See id. at 414.

63. See, e.g., St. Francis Hospital, 601 F.2d at 419; Presbyterian/St. Lukes Medical Ctr. v. NLRB, 653 F.2d 450, 456-57 (10th Cir. 1981) (requiring Board to "expressly consider congressional admonition" and to "focns on the 'disparity of interests' ").

64. See Presbyterian/St. Lukes, 653 F.2d at 457 n.6:

It is not the similarity of employees' training, hours, conditions and activities which determine the appropriateness of the unit. It is, rather the dissimilarity of interests relevant to the collective bargaining process that determines which eniployees are not to be included in a proposed unit. The proper approach is to begin with a broad proposed unit and then exclude employees with disparate interests. One should not start with a narrow unit, ... and then add professionals with similar interests.

65. 265 N.I.R.B. 1025 (1982).

66. See id. at 1029.

67. 271 N.L.R.B. 948 (1984). 
the disparity of interest test of the Ninth Circuit. ${ }^{68}$ St. Francis II was also short-lived. Joining several other circuits that rejected the Ninth Circuit's call for a "disparity of interest" test, 69 the Court of Appeals for the District of Columbia Circuit held that the "congressional adınonition" did not compel a disparity of interest approach and reinanded the case to the Board. ${ }^{70}$ Thus, in early 1987 the Board found itself again searching for an approach to health care bargaiming unit determinations that could command substantial judicial support. ${ }^{71}$

\section{St. Vincent Hospital: The Adjudication That Triggered Rulemaking}

The Board's initial response to its dilemma was to grant review and set oral arguinent in St. Vincent Hospital and Health Center, ${ }^{72}$ a post-St. Francis II case in which a regional director refused to find a separate RN unit appropriate. On May 4, 1987, the Board heard argunient on the lingermg issue of what test should be used for health care unit determinations, ${ }^{73}$ including particularly the question of the significance of the legislative history of the Health Care Amendnients of 1974. ${ }^{74}$ While St. Vincent was under consideration, the Board abandoned its effort to formulate a liealth care unit pohicy through adjudication and instead turned

68. See id. at 953.

69. See NLRB v. Walker County Medical Ctr., Inc., 722 F.2d 1535, 1539 n.4 (11th Cir. 1984); Watonwan Memorial Hosp., Inc. v. NLRB, 711 F.2d 848, 850 (8th Cir. 1983); Trustees of the Masonic Hall \& Asylum Fund v. NLRB, 699 F.2d 626, 641 (2d Cir. 1983).

70. See Electrical Workers Local 474 v. NLRB, 814 F.2d 697, 714-15 (D.C. Cir. 1987).

71. The Board later described the conflict in the circuits:

The Ninth and Tenth Circuits have held that the legislative history requires a "disparity-of-interests" analysis. Moreover, those circuits interpret the "disparity-of-interests" approach as sanctioning narrow units only if the differences in interests between the employees in the umit sought and other employees are so great as virtually to preclude organizing on a broader scale. Several other circuits, however, have rejected this rigid "disparity-of-imterests" approach, and have held instead that the Board may use a traditioual "community-of-interests" analysis, provided it weighs the public interest in avoiding unit proliferation against the employees' organizational rights. Other courts, while not expressly rejecting the rigid "disparity-of-interests" approach, have adopted the view that the Board inust take the congressional adinonition against unit proliferation into account in making hcalth care unit determinatious. Most recently, in Electrical Workers IBEW Local 474, the D.C. Circuit not only rejected the view that the ainendments mandate the use of a "disparity-of-interests" standard, but held that Congress' failure to ainend Sec. 9 of the Act (dealing with unit determinations) indicates that Congress implicitly approved the continued use of the "community-of-interests" approach in health care institutions. (The Court did indicate that the Board might, in its discretion, switch to a "disparity-of-interests" standard if it explained its action adequately.)

St. Vimcent Hosp. \& Hcalth Ctr., 285 N.L.R.B. 365, 366 n.8 (1987) (citations omitted).

72. Id. at 365. The decision to grant review was made on April 8, 1987. Id.

73. Id.

74. Act of July 26, 1974, Pub. L. No. 93-360, 88 Stat. 395 (codified as anended at 29 U.S.C. $\S \S 151-169$ (1988)). 
to rulemaking. The Board's deep frustration with the adjudicatory process on this issue was apparent in the language of its notice of proposed rulemaking. After reviewing the history of litigation simce the 1974 Amendments, the notice observed:

Thirteen years and many hundreds of cases later, the Board finds that despite its numerous, well-intentioned efforts to carry out congressional intent through formulation of a general conceptual test, it is now no closer to successfully defining appropriate bargaining units in the health care industry than it was in 1974. ${ }^{75}$

Nearly two inonths later, the Board announced its decision in St. Vincent. ${ }^{76}$ The decision disposed of the case by continuing to apply its disparity-of-interest test, and it asserted that the D.C. Circuit in St. Francis II had simply misunderstood the Board's rationale for this approach. ${ }^{77}$ At the same time, the Board pointed to the rulemaking it liad begun as its intended method for ultimately resolving the policy controversy. ${ }^{78}$ The Board indicated its intention to contimue to apply the disparity-ofinterest test until the rulemaking was concluded. ${ }^{79}$

\section{The Rulemaking}

In its incipient stage, the health care unit rulemaking presented novel questions for the Board that would have been routme for agencies

75. NPR I, 52 Fed. Reg. 25,142, 25,143 (1987).

76. 285 N.L.R.B. 365 (1987).

77. See id. at 367-69.

78. See id. at 365-66.

79. The Board explained its decision to continue applying current law as follows:

In the meantime, petitions will continue to be filed by labor organizations seeking to represent health care employees, and the Board is faced with deciding how to deal with those petitions while the rulemaking proceeding is pending. Three choices appear to be available: to take no action on such petitions until the final rule is issued; to make determinations under some new interim standard; or to continue to decide cases under extant Board law.

We reject the first option-deferring action pending issuance of the final rule-because it would leave the parties in limbo for an undetermined period of time-at least several months. In our view, such a lengthy period of maction certainly would not "assure to employees the fullest freedom in exercising the rights guarantced by the Act," and in fact would deprive them of those rights until the final rule was issued. In addition, since we have determined that the final rule will be prospective im application only, inaction pending the outcome of the rulemaking proceeding would merely result in delay, and in any event would not result in the final rule being applied to pending cases such as this.

We also choose not to process cases under any new interim standard, in part because any such standard necessarily would be of brief duration, ending sliortly after the final rule was promulgated. Moreover, the oral argument persuades us that it would be advisable to obtain empirical evidence before devising a new standard. Lastly, an interimi standard would add unnecessarily to the adjnstinents petitioners and employers must make as the Board moves from case-by-case adjudication to rulemaking.

Therefore, we have decided to contimue to process cases under existing law until the final rule has been issued. That is, we will continue to make bargaining unit determinations in the liealth care industry using the "disparity-of-interests" analysis announeed in St. Francis II, and wlich we have applied in subsequent cases.

St. Vincent, 285 N.L.R.B. at 366 (footnotes omitted). 
that regularly use notice and comment rulemaking. Most of these questions concerned the Board's authority to engage in rulemaking for umit determinations or basic ruleinaking procedure. Other questions reflected the uniqueness of this undertaking for the Board; sonie of these warrant attention before turning to the questions of authority and procedure.

\section{A. The Rationale for Rulemaking}

The decision to proceed by ruleniaking was inade at a Board ineeting on May 15, 1987,80 ten days after the oral argument in St. Vincent. Board ineinbers Babson, Stephens, and Cracraft voted in favor of proceeding by ruleniaking;:11 Chairman Dotson and Member Johansen voted against. ${ }^{82}$ Thus, even at the point the Board committed itself to rulemaking, there was sharp division as to the desirability of proceeding in this fashion. The transcript of this open ineeting provides an interesting perspective on just how fundanental the decision was given traditional Board practice and procedure. The exchanges from the transcript are part of a unique informal record of the views of Board members at a critical juncture in the Board's history.

Soine of the explanations offered by the Board inenibers for their positions reflected a fundamental disagreenent about the purpose and possible value of ruleniaking:

Chairman Dotson: What would we expect to learn in this process that we don't already know through the litigation, oral arguments that have taken place?

Member Babson: That's like asking what is it that we don't know. It's hard to say.

Chairman Dotson: Well, I'm wondering what conceivably could there be that would come forward in this process that would not have come forward im these other procedures? What kind of information?

Member Babson: I don't know that any of us can answer that question, Don, but as I understand the process, it provides the opporturity for any interested party, anybody arguably affected by the rule to come forward to provide us with information, some of which we may have already seen im the context of our case-by-case adjudication. ... It is impossible for us to state here and now, what is it we do not know until we give people the opporturity to tell us. ...

Member Stephens: Well, it seems to me that the thrust of the brief of the American Hospital Association [im St. Vimcent's] was that there has been this dynamic revolution in the hospital industry since 1974 so that things are inuch more highly integrated among the professions than ever before. And it seems to me that underneath that arguinent is

\footnotetext{
80. Transcript of Meeting of the NLRB, May 15, 1987, at 3.

81. Id.

82. Id.; see also St. Vincent Hospital, 285 N.L.R.B. at 365 n.6.
} 
the point that now more than ever there may be an increased risk of proliferation even with just more than a couple of units. . . . I don't think we could take cognizance of that argument in an adjudication because that's not evidence that's in the record. . . . I think, in a ruleinaking proceeding, in the hearing, and if other parties want to respond to that they should be given the chance to talk about what the current state of affairs in the healthcare industry is. . . .

Chairman Dotson: In that context, those things tend to be more assertions whereas in the adjudicatory process it takes the form of record evidence. I feel more comfortable with record evidence and if these changes oceur they will be reflected in the cases we receive later. ${ }^{83}$

This disagreement over the usefulness of rulemaking became even more contentious when the discussion turned to the question of whether to include a specific proposal in the notice of proposed rulemaking or merely to mdicate an intent to make a rule on the subject of health care units:

Member Babson: I would propose that the initial promulgation be a proposed rule that specifies proposed units in various sizes and kinds of healthcare institutions versus or as opposed to siniply soliciting comments $a b$ initio without any suggested delineation of units.

Member Johansen: My ouly comment again would be I would think that if we are going to recommend what appropriate units are, and we're going to say we're doing this because [we] rely upon our expertise and knowledge we have gained, that we jnst hist ... the units we have been going by. ... That gives some credence to the statement that all these 13 years we have gained all this knowledge and this is what we think is appropriate. ...

Mr. Subrin [Director of the Office of Representation Appeals]: I think you would be much better off to deviate a hittle bit from what you have done in the past, otherwise the unions are going to come rushing in and they are going to see this as your way of codifying and putting in grainte the units that they have fought tooth and nail against. ...

And by deviating a hittle bit, then if you ultimately decide to scratch ... [a] unit because ... it would be proliferative ... that would also make more credible that you histened to what was said in the hearing.

Chairman Dotson: That strikes me as a little cynical. . . .

Member Stephens: I don't see anything cynical about this. . . .

Chairman Dotson: Isn't it a fact that we appear to have a majority now in favor of giving the registered nurses a separate unit? And that this is a convoluted way to go about it?

83. Transcript of Meeting of the NLRB, May 15, 1987, at 20-22. 
Member Stephens: No, I don't think that's the case at all. Some people might perceive it that way, that might be your view, but that's not my view.

Member Babson: It's not my view either. That's a cymical view. What we're domg is that we're providing a basis for discussion and for those who are concerned about prejudgment, ... . any time that we put out a draft with some specifics in it, I suppose we're a candidate for being accused of prejudging ....

Chairman Dotson: I'm struck by the fact that in the oral arguments the representatives of both the employers and the unions showed no enthusiasm for going into rulemaking at this point and were much more concerned about the Board getting on with the decisionmaking process and getting cases decided. ... And I have not been able to see how changing the format of the decision changes the ultimate decision or is going to change what is laid before us. The principal difference I can see here is delay and confusion.

Member Stephens: Well, I don't see that. I don't see how it's going to be any more confusing or more delay-prone than the current state of affairs. ${ }^{84}$

The Board members also disagreed on the imphications of an initial rule proposal on ongoing adjudications:

Member Babson: Well, if we did it the way Jinn [Stephens] suggested then it should be clear to everyone that during the interim period that we will continue to adjudicate cases on a case-by-case basis according to whatever disposition we inake in the St. Vincent case. ... And, if parties choose to wait until the rulemaking process is completed, that's their business. . . .

Member Cracraft: . . . I think we will see people citing the proposed rule saying this nmit is appropriate because it conforms to the proposed rule.

Member Stephens: Well, we'll know what weight to give to that.

...

... We're making the decision. ${ }^{85}$

In the end the discussion returned to the fundamental question of the utility of rulemaking.

Chairman Dotson: As I understand it, you don't really know what you want to do about these umits and you beheve that ruleinaking will allow you to better decide what you want to do with these units.

Member Stephens: That's a loaded question. If you're going to accuse us of not knowing what we're doing, I think it's fair to say that this is a useful starting place. ... 
Chairman Dotson: I didn't say that you didn't know what you were doing. I said, do I understand correctly that you are undecided as to what to do?

Member Stephens: Well, that's a different question and I think that it's fair to say that we are ultimately undecided. This is a useful starting point.

Chairman Dotson: And you beheve that the rulemaking procedure will somehow provide you with something we don't already have from the Congressional hearings and the previous hitigation and the oral arguments and the many briefs that have been filed.

Member Stephens: That's right. . . . And, hopefully, I think the leap of faith that we are making here is that this will facilitate the administration of the Act. And, the fact that we cannot empirically demonstrate that, I don't think should deter us . . . ${ }^{86}$

Although the transcript cannot be expected to reflect completely the factors that underlay the judgment of individual Board ineinbers to support or to oppose rulemaking, the discussion reveals at least some attention to a number of issues that have surrounded calls for greater Board use of rulemaking: (1) whether rulennaking would stimulate the submission of useful empirical data or would simply attract the same generalized legal/pohicy arguments heard in adjudications; (2) whether the data that might be submitted would provide as rehable a basis for policymaking as the evidence that is admitted and tested through cross-examination in adjudications; (3) whetler loss of the assumed sensitivity of case-bycase consideration would be offset by the assumed speed and efficiency of a generalized approach; (4) whether the process of proposing and possibly inodifying proposed rules calls into question or enhances the concept of Board expertise; (5) whether the Board's regulated constituencies would find rulemaking credible and participate; and (6) whetler the Board could continue to adjust policy through adjudication leaving undertaken rulemaking.

The Board discussion in this meeting, as well as in one further public meeting, ${ }^{87}$ translated into a two-part rationale for proceeding with rulemaking, set out in the notice of proposed rulennaking in 1987.88 First, after briefly reviewing the unstable and hitigious background of health care unit determinations, ${ }^{89}$ NPR I suggested that there would be value im obtaining einpirical data from a range of affected parties on the effect of umit configuration on labor relations in the health care industry. ${ }^{90}$ Second, it asserted that the Board's thirteen-year experience with

86. Id. at 36-37.

87. See Transcript of Meeting of the NLRB, June 9, 1987.

88. See NPR I, 52 Fed. Reg. 25,142 (1987).

89. See supra text accompanying notes 57-71.

90. NPR I read: 
health care units reflected much commonality among health care facilities that led to "predictable groupings" of employees and provided the basis for proposing a specific rule for consideration. ${ }^{91}$ NPR I also noted the longstanding criticisin the Board had received from commentators for its reluctance to use rulenaking as a policyınaking vehicle.92 The rationale concluded with the Board's opinion that "ruleinaking, though perliaps time consuming at the outset, will be a valuable long-term investment, paying dividends in the form of predictability, efficiency, and more enliglitened determinations as to viable appropriate units . . . .93

\section{B. The Authority for Rulemaking}

\section{Section 6 of the NLRA expressly grants the Board ruleinaking} authority. ${ }^{94}$ Thus, the general authority of the Board to engage in

It is clear to us that the key element in the Board's avoidance of proliferation is to designate how many units will be deemed appropriate im a particular type of health care facility. In so doing, the Board must effectuate section 7 rights by permitting bargaiming in cohesive units, units with interests both shared within the group and disparate from those possessed by others; weighed against this inust be Congress' expressed desire to avoid proliferation in order to avoid disruption in patient care, unwarranted unit fragmentation leading to jurisdictional disputes and work stoppages, and increased costs due to whipsaw strikes and wage leapfrogging. Though the Board has of times made broad generalizations as to which types of unit configurations would or would not lead to probiferation and the catalogne of undesired results, it ... has never obtained empirical data on these matters. This, along with the still unsettled state of the Board's past, doctrinal efforts after so many years, is [one of the] major reasons for the Board's deciding to engage in rulemaking.

52 Fed. Reg. at 25,143 .

91. NPR I states:

Another major reason [for the rulemaking] is a reflection of the Board's extensive experience. The Board has in the last 13 years received many hundreds of petitions for health care units. Generally, the units requested have been im approximately six, predictable groupings: registered nurses, other professional employees, technical employees, business office clerical employees, service and maintenance employees, and skilled maintenance employees. Ouly occasionally have units of guards or physicians been sought. It is our observation that these groups of employees generally exhibit the same internal characteristics, and relationship to other groups of employees, in one health care facility as do like groups of employees at other facilities. To put the matter another way, the various health care facilities we have examined over the years have looked very much the same as other facilities of the same type: large acute care hospitals, small acute care hospitals, and nursing homes.

Id. at 25,143-44.

92. The Board cited most of the critical commentary in the literature. See id. at 25,144 n. 33 ; see also supra note 3. At one point, the Board fully quoted one of the bluntest expressions of criticism:

"Rather than providing a basis for decisions that ouly a supposedly expert agency could make-by evaluating the available empirical, economic literature and systematieally distilling the accunulated experience of Board personnel and of the labor relations commumity generally - the Board acts as a kind of Article I "Talmudist" court, parcing precedent, divining the true meaning of some Supreme Court ruling, and balancing in some mysterious fashion competing, yet absolute-sounding values."

NPR I, 52 Fed. Reg. at 25,143 (quoting Estreicher, supra note 3, at 172).

93. NPR I, 52 Fed. Reg. at 25,144 .

94. Section 6 provides that "[t]he Board shall have authority from time to time to make, amend, and rescind, in the manner prescribed by [the APA], such rules and regulations as may be necessary to carry out the provisions of this subehapter." 29 U.S.C. $\$ 156$ (1988). 
rulemaking was not in doubt. The section 9(b) directive to the Board to determine appropriate units, however, provides in part: "The Board shall decide in each case whether . . . the unit appropriate for the purposes of collective bargaining shall be the employer unit, craft unit, plant unit, or subdivision thereof ...."95 Anticipating arguments that the " $\mathrm{m}$ each case" language precluded the use of ruleinaking for unit questions, NPR I set out the basis for the Board's contrary view.

First, the notice quoted in full Professor Kenneth Culp Davis's emphatic conclusion that the language could not have been intended to have such effect:

Do the words "im each case" mean that the Board is prohibited from classifying problems, from developing rules or principles, or from relying on precedent cases which establish narrow or broad propositions? The answer has to be clearly no; the Board may decide "in each case" with the help of such classifications, rules, principles, and precedents as it finds useful. The mandate to decide "in each case" does not prevent the Board from supplanting the original discretionary chaos with some degree of order, and the principal instruments for regularizing the system of deciding " $m$ each case" are classifications, rules, principles, and precedents. Sensible men could not refuse, to use such imstruments and a sensible Congress would not expect them to.96

The Notice then referred to both judicial and scholarly observations that the unit determination process could benefit particularly from rulemaking by providing a vehicle for obtaining and evaluating empirical data concerning how various unit configurations affect bargaining.97 Fimally, it offered examples of the sort of empirical questions participants im the rulemaking process might address. ${ }^{98}$

95. Id. $\$ 159(\mathrm{~b})$ (emphasis added).

96. NPR I, 52 Fed. Reg. at 25,144 (quoting KenNeth C. Davis, Administrative Law TEXT 145 (3d ed. 1972)).

It is interesting to note that the scholarly commentary that eucouraged the Board to make greater use of its rulemaking authority, including the view of Professor Davis, was the subject of discussion in the second open ineeting at which the content of NPR I was discussed:

Mr. Babson: I don't think for example, that the document should suggest that the only reason why we are engaging in rulennaking, is because all these distinguished commentators think that we should. I think that the Board in its judgment, in its colleetive wisdom, I think that we are aware of this commentary.

Much of it is well taken. But, really, the impetus for the decision is that there is, I think, a view that it will benefit the agency; that the time has come to try to avoid soine of the relitigation that we have experienced.

...

That is not to say that [the cominentary] ncedn't be referred to. I think that we can probably refer to it, but, I don't think that the reason that we are doing it is because we were all in law school at some time when Kenneth Davis was criticizing the NLRB for not engaging in ruleinaking.

Transcript of Meeting of the NLRB, June 9, 1987, at 10-11.

97. See NPR I, 52 Fed. Reg. at 25,145.

98. See id. The Board described its interest as follows: 
Ultimately, the "in each case" language became the basis for one of the three inajor legal arguments inade in challenging the final rule. 99 The imitial notice of proposed rulennaking addressed this potential issue only in the limited fashion described above. This inay have been the product of a view that the issue was not a particularly significant one or that the notice of proposed ruleinaking was not the proper vehicle for fully setting forth an agency's position on a legal question.

\section{The Terms of the Proposed Rule}

The rule proposed in NPR I covered only acute care hospitals and nursing homes, thus excluding such facilities as psychiatric hospitals, for which unit determinations would continue to be inade on a case-by-case basis. The proposed rule provided in pertiment part:

(a) With respect to employees of "health care institutions" as defined in section 2(14) of the Act, no petition for initial organization shall be entertained, except under extraordimary circumstances, if the petition seeks certification in a bargaining unit not in substantial accordance with the provisions of this rule. The following shall be the only appropriate units, except that any combination will also be appropriate, as the union's option and so long as the requirements of section 9(b) (1) and (3) [governing professionals and guards] are met:

(1) Appropriate units in large, acute care hospitals, which shall be defined as all acute care hospitals having more than 100 patient beds:

(i) All registered nurses.

(ii) All professionals except for registered nurses and physicians.

(iii) All physicians.

The Board wants to learn how various bargaining units affect legitinate concerns of both unious and health care employers. For example, when registered nurses have been grouped with other professionals, have their interests been properly represented? Has the bargaining, when it has occurred im all-professional groups, nonetheless proceeded on the basis of each separate profession? Have wage rates been negotiated separately despite the all-professional units? When they have existed, have separate professional groupings resulted in imterruption in the delivery of health care? Wage whipsawing? Jurisdictional disputes? These are merely examples of the types of questions that should be addressed by anyone testifying for or against separate units, such as registered nurses, business office clericals, technicals, maintenance employees, etc. The Board is not seeking at the oral hearings the "opinions" and further legal arguments of counsel, which inay be submitted as cominents, but, rather, actual, empirieal, practical evidence offered by industry and union representatives who have thenselves participated in or observed bargaining in the health care industry in various configurations. The Board also desires evidence from witnesses with direct knowledge about any recent changes in the delivery of health care, such as cost containment, allegedly greater integration of function between eategories of health care employees, and changes im function of specific classifieations of hcalth care enployees, including greater or lesser degrees of specialization, that may have an inipact on the question of Id. appropriate units.

99. See, e.g., Brief for Petitioner at 13-25, American Hosp. Ass'n v. NLRB, 111 S. Ct. 1539 (1991) (No. 90-97). 
(iv) All technical employees.

(v) All service, maintenance and clerical employees except for guards.

(vi) All guards.

(2) Appropriate units in small, acute care hospitals, which shall be defined as all acute care hospitals having 100 patient beds or fewer [and all nursing homes]:

(i) All professional employees.

(ii) All technical employees.

(iii) All service, inaintenance and clerical einployees except for guards.

(iv) All guards. ${ }^{100}$

The proposed rule thus distimguished between large and small hospitals by providing for six units in the former and only four in the latter. ${ }^{101}$ The notice asserted that these units reflected the groupings of employees across a broad range of health care facilities and that these groups were essentially "predictable" from the body of Board adjudications smce the Health Care Amendments, and thus the proposed rule reflected the Board expertise developed over a period of thirteen years. ${ }^{102}$ After providing a brief explanation for each unit, the notice indicated that the "extraordinary circunistances" exception would be apphed restrictively to accomphsh the hitigation-reducing purpose of the rule. ${ }^{103}$

\section{The Procedure for the Rulemaking}

Although the notice and comment procedures of section 553 of the APA would have required only an opportunity for written comments on the proposed rule, ${ }^{104}$ the Board decided for a variety of reasons to hold

100. NPR I, 52 Fed. Reg. at $25,149$.

101. The Board explained:

The Board has tentatively decided, based on its experience, that larger hospitals, with their larger nnmbers of employees im each category, may warrant one or two additional units. In smaller facilities, it is likely that employees will have more contacts with one another, may to some extent perform one another's work, and generally may share imterests more than groupings in larger hospitals. A shightly lesser degree of specialization seems also probable. Recognizing that perfection is impossible in this area, but also being intent on not hitigating the precise boundaries of the "small hospital" in each case, the Board has tentatively determined that acute care hospitals of more than 100 patient beds will be deemed "large"; acute care hospitals of 100 patient beds or fewer will be deemed "snuall."

Id. at 25,146 .

102. See id. at 25,144; see also Appendix B, "Results of Case-by-Case Adjudications" (Board submission at Sept. 14, 1987 hearing).

103. NPR I, 52 Fed. Reg. at 25,145. The Board stated: "Thongh an 'extraordinary circumstances' exception has been included, it is anticipated that the exception will be little used and limited to truly extraordinary situations; the exception is to be construed narrowly and is not intended to provide an opportunity (or looplole) for redundant litigation." Id.

104. See 5 U.S.C. $\$ 553$ (c) (1988) ("After notice required by this section, the agency sliall give interested persons an opportumity to participate in the rule making through submission of written data, views, or arguments with or without the opportunity for oral presentation.") (emphasis added); 
public liearings, to receive oral and written comments, and to permit limited cross-examination. ${ }^{105}$ First, and perhaps most important, was the desire to assure affected parties that there would be the fullest opportumity to participate as the Board undertook a new method of policy formulation. ${ }^{106}$ Second, there was some concern that without oral testimony and cross-examination, tlie Board would receive through written submissions ouly legal arguments of the kind it traditionally heard in adjudications. ${ }^{107}$ Third, the notion of a contestcd proceeding, with one group of participants testing the positions of the opposing participants, was consistent witl the model of labor-management relations the Board and its constituencies generally accepted. ${ }^{108}$ Finally, there was a view that, $\mathrm{m}$ this novel undertaking, the Board should minimize the likelihood of legal challenge to the action on procedural grounds. ${ }^{109}$

Hearings were sclieduled and held at three locations: Washington, D.C., on August 17 and 18, 1987; Chicago on August 31 and September 1, 1987; and San Francisco on Septeinber 14-16, 1987.110 The objective was to permit the widest opportunity for participation through geographical dispersion of the hearing venues. A fourth hearing was latcr held in Washington, D.C. on October 7-9 and 13-16, 1987. The initial comment period was scheduled to end October 30, 1987 (120 days after the imitial notice), 111 but was extended threc times. ${ }^{112}$

After establishing the preliminary procedural requirenents for gaining access to the hearing, ${ }^{113}$ NPR I outlined the procedure for the hearings:

see also American Trucking Ass'n v. United States, 344 U.S. 298, 319-20 (1953); SchWARTZ, supra note 6 , at 196.

105. Interviews, supra note 9.

106. Id.

107. Id.

108. Id.

109. Id.

110. See NPR I, 52 Fed. Reg. at 25,148 (scheduling opening day of each hearing).

111. See id.

112. See Collective-Bargaining Units in the Health Care Industry, 53 Fed. Reg. 33,900 (1988) [hereniafter NPR II] (second notice of proposed rulenıaking).

113. Preliminarily, NPR I prescribed:

Persons wishing to present oral testimony at any one of the specified locations should notify the Office of the Executive Secretary ... no later than July 24, 1987, advising it of the location at which the witness wishes to testify. Thereafter, all witnesses should submit to the Executive Secretary ... eight copies of either the written text or a summary of their presentations no later than 1 week prior to the commeneentent of the hearing at which they wish to testify. Copies of these texts and summaries will be placed in the docket ... and will be available at the Executive Secretary's Office, and also at the hearing location where the witness intends to testify, for examination by interested persons.

52 Fed. Reg. at 25,148. 
An administrative law judge will preside over the hearings, which will be informal, legislative-type proceedings at which there are no formal pleadings or adverse parties. In general, oral presentations from individual witnesses will be limited to 20 minutes each, except that the presiding judge may impose a greater or lesser period, at the judge's discretion, if he or she deems it appropriate. Participants may desire to ask questions or [sic] crucial issues following a presentation. Such questions may be permitted by the judge, limited to approximately 15 minutes per questioner. . . . The judge shall have discretion to modify the time for questioning, and shall have further discretion to impose other guidelines for the orderly and efficient conduct of the hearing. ... .

The Board will be represented at the hearings by a member of its staff. The judge and the Board representative shall have the right to question persons making an oral presentation as to their testimony and any other relevant matter. ${ }^{114}$

The Board assigned senior Administrative Law Judge Bernard Ries to the hearings. Judge Ries thereafter periodically refined the procedural guidelines for the rulenraking, in consultation with the participants and in hight of developinents at the hearings. ${ }^{115}$

At the first Washington hearing, twenty witnesses appeared and 496 pages of testimony were taken. ${ }^{116}$ At the Chicago hearing, twenty-seven witnesses appeared and 521 pages of testimony were taken. ${ }^{117}$ At the San Francisco hearing, thirty-nine witnesses appeared and 762 pages of testimony were taken. ${ }^{118}$ Finally, at the second Washington hearing, fiftyeight witnesses appeared and 1766 pages of testimony were taken. ${ }^{119}$ The witnesses included enployees in niost of the job classifications at issue, national and local urion officials representing these einployee groups, health care einployers, representatives of health care trade associations and professional organizations, and individual health care professionals and academics. ${ }^{120}$

114. Id.

115. For example, the judge undertook to adjust the time requirements for advance submission of comments to accommodate the participants' needs and sought to develop groupings of similarly situated participants to minimize repetitive questioning in the hearings.

116. NPR II, 53 Fed. Reg. at 33,900.

117. Id.

118. Id.

119. Id.

120. Id. Accommodating the large number of witnesses, and participants interested in crossexamining wituesses, posed various problems for the presiding judge. The published procedurerequiring written statemeuts in advance, limiting time for presentation and cross-exammation, and grouping representatives with common interests-proved soinewhat dificult to implement. It was clear froin the procedural charter that the Board intended the judge to perform only a traffic control function, and that it wanted participants to have as much flexibility in making their presentations as 
Clearly, the choice of oral hearings did provide the opportunity for broad participation. Unions, particularly those with the nost at stake, ${ }^{121}$ participated nore actively and more thoroughly in the proceedings than did health care managenient representatives. ${ }^{122}$ Some of the umions presented testimony that included enipirical data on the effect of unit configuration on health care labor relations, particularly in regard to strike activity. ${ }^{123}$ The industry testimony was not as enpirically oriented and rehed heavily on general pohicy argunients and legal issues related to the "congressional admonition." 124 Although the Board had sone imitial concern that either side might choose not to participate substantially in a rulenraking, ${ }^{125}$ it is not entirely clear why nranagenrent's participation was nore limited than that of the unions.

A number of explanations are possible. Any rule establishing standard health care units would to some extent constrain litigation opportunities for managenient in resistnig unionization and, in turn, would likely speed the certification process. Moreover, the particular units proposed im NPR I were simply niore nunierous than those that the unions had sonietimes been able to achieve througln litigation. It is thus possible that some healtli care industry coniponents assunied, given the division in the Board on the question of whether even to proceed to rulemaking, that the nore limited the participation, the less likely tlie Board would ever issue a final rule. Similarly, if the industry assumed that the Board was firmly committed to the units set forth in the nitial proposal, sone nray have reasoned that active nranagenient participation would ouly lend credibility to a proceeding that would not lead to a favorable result from the nidustry perspective. On the otlier hand, the unions nray liave assunned

reasonably possible. The judge's supervisory functions were limited to the development of the hearing record; the Board staff supervised the development of the non-hearing record. Thus, in organizing the hearings and ruling on time requests and opportunities for questioning, the judge's approach was generous. While multiple hearings at multiple locations enhanced the opportunity for participation, it also created certain scheduling and traveling probleuns, especially for participants who felt it necessary to participate at each location. Finally, although the opportunity for questioning (crossexamination) gave the hearings and ultimately the record a richer character, it necessarily extended the time required to complete the hearings. Ultimately, given the tolerant standard applied, some of the questioning (like soine of the underlying presentations) contributed only inarginally to the value of the record.

121. Among the inost active participants were unions representing registered nurses and skilled maintenance workers. Interviews, supra note 9.

122. Id.

123. Id.

124. Id.

125. See id. Soine Board members had informal conversations with union and managenent representatives to determine whether the parties would participate actively in a ruleunaking if one were undertaken. 
that the initial proposal was the deceptive opening gambit in a proceeding intended to lock in the more restrictive unit position the Board had taken in recent years, and that their active participation was therefore essential as a defensive matter. Both sides might also have perceived the initiation of the proceeding as offering something of an olive branch to umions that had come to believe that the Board was increasingly hostile to their interests. How this might have affected participation is uncertain. It is clear, however, that the very uniqueness of the proceeding for the Board undoubtedly encouraged speculation on both sides as to the significance of the undertaking, and thus may have affected the vigor of participation.

\section{E. The Product of the Initial Comment Period and NPR II}

During the four hearings, 144 witnesses testified, producing a combined transcript of 3545 pages. ${ }^{126}$ Additionally, the Board received 315 written comments totalling approximately 1500 pages. ${ }^{127}$ The Board indicated in the second notice of proposed rulemaking (NPR In) that it was "gratified at, and appreciative of, the interest shown in these proceedings" and that it was "now far better qualified to resolve the issues raised." 128 NPR II, which covered thirty-six pages in the Federal Register, comprehensively reviewed the rulemaking record. In addition to addressing the substantive issues related to health care unit deterininations, NPR II reaffirmed the desirability of proceeding by rulenaking. The notice emphasized the relatively uniform Board approach to health care units in adjudications and the considerable similarity among health care institutions. ${ }^{129}$

Most iniportantly, the second notice made a numiber of changes in the initially proposed rule and provided a detailed explanation based on

126. NPR II, 53 Fed. Reg. 33,900, 33,900 (1988).

127. Id.

128. Id. at 33,900-01.

129. See id. at 33,903. The Board observed:

Our adjudicatory decisions as to appropriate units in the health care industry, where the facts of each case were painstakingly examined in numerous lengthy and costly representation case proceedings, have been remarkably uniform in results, varying only when the Board changed doctrinal formnlations, e.g., from "community" to "disparity" of interests. Thus, for example, from 1975 to 1984, despite lengthy adjudicatory proceedings the Board found $R N$ units appropriate in 24 out of 25 published cases; technieal units appropriate in 18 out of 18 cases; business office clerical units appropriate in 8 out of 8 cases; etc. Though adjudication led to varying results for skilled inamtenance units, that was largely a function of a single Board inember, Member Jenkins, reaching different results on different records. Other inembers were, individually, remarkably uniform, despite alleged differences in the records. E.g., Member and Chairman Fanning found the separate maimtenance unit appropriate 29 out of 29 times; Chairman Murphy, 26 out of 26 times. Continuing to determine appropriate units in this way seems unproductive, especially considering the lack of universal judicial approval of any single doctrinal approach.

Id. (citations omitted). 
the rulemaking record for each change and for each component of the revised rule. ${ }^{130}$ The notice also provided for an additional comment period "[b]ecause this is the Board's first major effort at substantive rulemaking, and because the Board is desirous of giving all interested parties a further opporturity to comment on the proposed rules, includmg the substantial revisions ...."131

The revised proposed rule eliminated the large-small hospital distinction, observing that "[t]he vast majority of representatives of both unions and employers appeared to agree that hospital size is not well correlated with integration or division of labor, and opposed a rule differentiating between large and small hospitals."132 The revision also limited coverage of the rule to acute care hospitals, thus excluding nursing honies because "there are not only substantial differences between nursing homes and hospitals but also significant differences between the various types of nursing homes which affect staffing patterns and duties."133 Most significantly, having eliminated the special provisions for smaller hospitals, the revision increased the number of appropriate units for all hospitals from six to eight, carving out separate units for "skilled maintenance einployees" and "business office clericals," and leaving a possible residual umit of "all non-professional employees."134

130. See id.

131. Id. at 33,901 (citing Mark D. Shepard, Note, The Need for an Additional Notice and Comment Period When Final Rules Differ Substantially from Interim Rules, 1981 DUKe L.J. 377).

132. Id. at 33,927 .

133. Id. at $33,927-29$.

134. Id. at 33,933. The Board explained that the changes were based on the empirical evidence adduced during the initial comment period considered in light of a range of factors traditionally considered in unit analysis and in light of the congressional admonition concerning proliferation of units. See id. at 33,904-06. The Board observed:

Although under ruleniaking we sliall attenpt to avoid the doctrimal formulations utilized under adjudication, many of the factors we consider will be similar. Thus, anjong the factors to be considered will be umiqueness of function; training, education and licensing; wages, hours and working conditions; supervision; employee interaction; and factors relating to collective bargaining, such as bargaining history, matters of special concern, etc. Location and scope of the job market may be relevant: i.e., whetler the classification is part of a job market external to the facility or even to health care, or rather sliares a job market with others in the facility or, perhaps, in the areawide health care comınunity; job market is a factor not extensively considered under adjudication, probably because evidence regarding it is not likely to be introduced during the litigation of a particular case. In addition to these factors, should the evidence reveal the possibility of a separate unit, we shall examine the likelihood that such a separate unit would result in interruption in the delivery of health care, wage whipsawing, or jurisdictional disputes, matters with which Congress expressed concern during the deliberations that preceded the 1974 amendments. The emphasis, during our rulentaking deliberations, has been and will be on tlie empirical-what, according to the mass of evidence presented, is warranted and will facilitate collective bargaining without jeopardizing the public interest-as opposed to prior, more doctrinal, more conceptually oriented, determmations. We are confident we are now a better informed administrative body in exercising the substantial discretion which we possess in the area of unit determinations.

Id. at 33905-06 (citations oinitted). 
Although the increase in the number of units from six to eight was the only truly controversial change in the amended proposal, it was consistent with certain adjudicated unit determinations and was well-supported by evidence presented in the initial comment period.135 Thus, it appears the Board could reasonably have adopted the changes at that point and announced a final rule. The Board formally explained its decision not to do so in terms of the novelty of the proceeding and the desire to provide the fullest opportunity for participation. ${ }^{136}$ As a result, over six months elapsed between the second notice and the adoption of the final rule, which was essentially the same as the revised rule in the second notice. Given the unclarity of the law on the need for additional comment periods, ${ }^{137}$ however, the Board's caution in seeking a second round of comments seems understandable in its initial encounter with substantive rulemaking.

Nevertheless, procedural caution may not fully explain the decision to solicit further comments. When the decision to issue a second notice of proposed rulemaking allowing an additional comment period was made on July 1, 1988, the Board consisted of four members: Babson, Cracraft, Johansen and Stephens. Chairman Dotson had resigned effective December 16, 1987. Moreover, Member Babson, who was part of the initial 3-2 majority that decided to undertake rulemaking, had already announced his resignation from the Board effective July 31, 1988. ${ }^{138}$ Thus, at this crucial juncture in the proceeding, the Board was about to have its meinbership reduced to three, only two of whom supported the rulemaking. Member Babson's participation in the vote to continue the proceeding created a 3-1 majority for going forward with

135. See, eg., Results of Case-by-Case Adjudications (Appropriate Units in the Health Care Industry) (submission by the National Labor Relations Board, Office of Representation Appeals at the September 14, 1987 hearing in San Francisco summarizing adjudicated unit determinations concerning separate RN urits, technical units, maintenance urits, and office clerical units).

136. See NPR II, 53 Fed. Reg. at 33,901.

137. See NPR I, 52 Fed. Reg. at $25,142$.

138. The following table describes the Board composition during the ruleunaking proceeding:

TABLE

Board Coinposition During Rulemaking

\begin{tabular}{|c|c|c|c|c|c|}
\hline $\begin{array}{l}\text { Member } \\
\text { Name }\end{array}$ & $\begin{array}{l}\text { Began } \\
\text { Service }\end{array}$ & $\begin{array}{l}\text { NPR I } \\
7-2-87\end{array}$ & $\begin{array}{c}\text { NPR II } \\
9-1-88\end{array}$ & $\begin{array}{c}\text { Final Rule } \\
4-21-89\end{array}$ & $\begin{array}{l}\text { Ended } \\
\text { Service }\end{array}$ \\
\hline $\begin{array}{l}\text { DOTSON } \\
\text { JOHANSEN }\end{array}$ & $\begin{array}{r}3-7-83 \\
5-28-85\end{array}$ & $\begin{array}{l}\mathrm{X} \\
\mathrm{X}\end{array}$ & $\mathrm{x}$ & $\mathrm{x}$ & $\begin{array}{l}12-16-87 \\
6-15-89\end{array}$ \\
\hline BABSON & $7-1-85$ & $\mathrm{x}$ & n1 & & $7-31-88$ \\
\hline STEPHENS & $11-1-85$ & $\mathrm{x}$ & $\mathrm{x}$ & $\mathbf{x}$ & continues \\
\hline CRACRAFT & $11-14-86$ & $\mathrm{x}$ & $\mathrm{X}$ & $\mathrm{x}$ & continues \\
\hline HIGGINS & $8-29-88$ & & $\mathrm{n} 2$ & $\mathrm{X}$ & $11-22-89$ \\
\hline DEVANEY & $11-22-88$ & & & $\mathrm{x}$ & continues \\
\hline
\end{tabular}

n1 Participated in vote to issue NPR II (7-1-88)

n2 Did not participate in vote to issue NPR II (7-1-88) 
the rulemaking, while not committing the Board to a final rule that might have been supported by only a 2-1 majority at the time of publication. Whether this was actually a factor in the Board's decision to provide an additional comment period is not as miportant as the fact that the clianges in the composition of the Board not only posed the usual prospect for substantive policy shifts, but also threatened to undermine the decision to undertake ruleinaking. ${ }^{139}$

One other possible Board motivation in providing an additional comment period deserves mention. NPR II certified that the rulemaking would comply with the provisions of the Regulatory Flexibility Act. ${ }^{140}$ NPR I did not contain a Regulatory Flexibility Act certification. The desire to correct this omission might, in part, have motivated an additional comment period. ${ }^{141}$

\section{F. The Final Rule}

The notice of adoption of a final rule was published on April 21, 1989.142 It indicated that the Board had received approximately 1500 comments during the additional comment period; roughly thirty supported the proposed rule in whole or part, while roughly 1465 opposed it. ${ }^{143}$ It also indicated that approximately one-lialf of the 1465 comments in opposition to the rule were form letters, "for the most part containing brief arguments without supporting detail." 144 The notice explained that

139. In the Final Rule notice the Board indicated that an argument had been made in the second comment period that it should not promulgate a final rule without a full complement of Board meinbers. The notice explained further that the issue was now moot inasinuch as there was a full complement. See Final Rule, 54 Fed. Reg. 16,336, 16,337 (1989).

140. 5 U.S.C. $\S \S 601-612$ (1988). The certification in NPR II read as follows:

As required by the Regulatory Flexibility Act, 5 U.S.C. [\$§]601[-612 (1988)], the Board certifies that the proposed rule will not have a significant economic inpact on small entities. Prior to this rule, parties before the Board were required to litigate the appropriateness of a unit for election purposes if they could not reach agreement on the issue. Upon enactinent of this rule, parties will no longer be required to engage in litigation to determine the appropriateness of units, thereby saving all parties the expense of litigation before the Board and the courts. To the extent that organization of enuployees for the purpose of collective bargaining will be fostered by this rule, thereby requiring snall entities to bargain with unions, and that employees may thereby exercise rights under the National Labor Relations Act, as anended (29 U.S.C. [\$§]151[-168 (1988)]), the Board notes that such was and is Congress' purpose in enacting the Act and the health care amendinents thereto.

NPR II, 53 Fed. Reg. at 33,934.

141. The final rule reaffirmed this certification. See Final Rule, 54 Fed. Reg. at 16,346.

142. See id. at 16,336 .

143. Id.

144. Id. The Board elaborated:

The inost coinnon form letter, submitted by over 600 correspondents, briefly exhorts the Board to return to the case-by-case approach and to find appropriate only two units, all professionals and all nonprofessionals, plus the statutorily-mandated separate unit of guards. Otherwise, say these commenters, their ability to provide coinprehensive, coordinated care would be adversely affected.... The form letter contains blank spaces for such 
generally the additional comments "mirror[ed] those made during earlier points in tlie rulemaking" and listed nineteen categories into whicli the arguments fell. ${ }^{145}$ From this grouping the Board separated tliose issues it believed it liad dealt with tlioroughly in NPR I and NPR II from new issues that were dealt with separately in the final notice. ${ }^{146}$ With one exception, tlie latter arguments related to the substance of tle rule.

The exception was contained in a section entitled Rulemaking, in which the Board for the first time thoroughly addressed the argument that tlie "in each case" language of section 9(b) of the Act precluded the use of rulemaking for unit determinations. ${ }^{147}$ The section referred to the legislative history of tlie provision, and to the commentary arguing against this construction of the statute. ${ }^{148}$ It also noted tliat the Board's adjudicative decisions in unit cases effectively created "rules" of general applicability to determine appropriate units. ${ }^{149}$ Moreover, for the first time in tlie rulemaking, the Board referred to Heckler v. Campbell, ${ }^{150}$ a Supreine Court decision upliolding the autliority of the Secretary of Healtlı and Hunıan Services to use rules to limit the issues requiring case-by-case consideration under a statutory sclieme that, like section 9(b) of tlie NLRA, required individual determinations. ${ }^{151}$ Lastly, the notice eclioed the earhier notices by expressing confidence in the value of tlie product of the rulemaking. At the saine time, the final notice recognized that the undertaking did not resolve all imcertainty witli respect to liealth care unit determinations:

Finally, although we are highly satisfied with this rulemaking proceeding both because of the large amount of valuable information it has given us and because, based on that information, we are confident we have moved towards eliminating much of the unnecessary uncertainty existimg in this area, we are under no illusions that the answers we now provide will necessarily solve all health care unit problems, for all time. This is our first venture in major, substantive rulemaking. At

information as "(name of organization)"; "(number)" of health care facilities owned by the commenter; and "(number)" of employees; one submitted copy of the form letter did not have the blanks filled in

Id.

145. Id. For a description of the categories, see id. at $16,336-37$.

146. See id. at 16,337 .

147. See id.

148. See id. at $16,337-39$.

149. See id. at 16,338 . The Board gave the following examples:

(1) [t]hat single facility units are presumptively appropriate; (2) that residual units are not separately appropriate when sought by an incumbent; (3) that plant clericals and office clericals do not constitute an appropriate unit absent agreement of the parties; (4) that the appropriate umit in decertification elections is the certified or recognized umit.

Id. (citations omitted).

150. 461 U.S. 458 (1983).

151. See Final Rule, 54 Fed. Reg. at 16,338 . 
some future date, after the rule has had a fair trial, it may be appropriate to reexamine the rule to determine how well it has worked, whether new developments have changed our underlying assumptions and require different conclusions, and whether some other provisions might " improve those now promulgated. 152

The final rule maintained the eight-umit structure proposed in NPR II, ${ }^{153}$ but added definitions of key terms. ${ }^{154}$ Most importantly, the rule added a proviso that a "unit of five eniployees or fewer shall constitute an 'extraordinary circumstance' removing the case from strict application of the rule, and the Board will consider by adjudication what the appropriate scope of the umit should be."155

Member Johansen was the only member to dissent formally fronı the product of the rulenaaking, ${ }^{156}$ consistent with his opposition to the use of ruleniaking in NPR II. ${ }^{157} \mathrm{He}$ adopted the position that the use of rulemaking for determining health care units was both inappropriate and undesirable. He first argued that the "in each case" language of section 9(b) foreclosed rulemaking for particular units. ${ }^{158} \mathrm{He}$ further asserted that even if the promulgation of such a rule were permissible, it would not resolve the disagreement that existed in the Board and in the courts over the meaning of the 1974 Health Care Amendments. This issue, according to Johansen, was a niatter that should properly be resolved by a definitive Suprenie Court ruling. ${ }^{159}$ Finally, Johansen argued that the health care industry could not tolerate the rigidity of the rule, nor could the Board sustain the inflexibility of the rule in light of the evidence received and the changes niade over the course of the rulemaking. 160

\title{
IV. Litigation Challenging the Rule
}

The final rule was published April 21, 1989, and was to becone effective thirty days later. On the day the rule was published, however, the AHA, a trade association representing over 5000 hospitals, filed an action in the U.S. District Court for the Northern District of Illinois challenging the rule and seeking declaratory and injunctive relief. ${ }^{161}$

\author{
152. Id. at 16,339 . \\ 153. See id. at 16,348 . \\ 154. See id. \\ 155. Id. at 16,342 . \\ 156. See id. at 16,347 . \\ 157. See NPR II, 53 Fed. Reg. at 33,934-35. \\ 158. See Final Rule, 54 Fed. Reg. at 16,347. \\ 159. See id. \\ 160. See id. \\ 161. American Hosp. Ass'n v. NLRB, 718 F. Supp. 704, 705 (N.D. Ill. 1989).
}


District Judge James Zagel issued a preliminary injunction against enforcement of the rule ${ }^{162}$ on May 22, 1989, and, on July 25, 1989, declared the rule unlawful and granted a permanent injunction. ${ }^{163}$ On April 11, 1990, the Court of Appeals for the Seventh Circuit reversed, ${ }^{164}$ but granted the AHA's motion to stay the order vacating the district court order pending the disposition of an AHA petition for certiorari in the Supreme Court. ${ }^{165}$ The Supreme Court granted the petition, ${ }^{166}$ and, on April 23, 1991, affirmed the Court of Appeals. ${ }^{167}$

\section{A. District Court Proceeding}

Upon issuing the preliminary injunction on May 22, 1989, the district court set an expedited briefing schedule for the hearing on the permanent injunction. The issuance of the preliminary injunction im effect required the Board to establish a policy for processing petitions during the pendency of the hitigation challenging the rule. As previously explained, at the outset of the rulemaking the Board had decided to continue processing election petitions under the "disparity of interest" standard developed througli adjudication until a rule was issued. ${ }^{168} \mathrm{Few}$ petitions, however, were filed during this period, presumably because the standards of the proposed rule were more favorable for many key health care unions than the existing standards and minimized the risk of litigation delays. This suggested that a nuniber of health care unions had simply delayed petitions or further organizing efforts pending the completion of the rulemaking. Thus, with a completed rulemaking but without an enforceable rule, the Board faced a dilemma: Either it would have to continue to process petitions under the pre-rule standards that were now arguably mconsistent with the position it had taken in the rulemaking, or it would have to suspend processing petitions while it sought to have the mjunction overturned. It chose essentially the latter course.

On May 30, 1989, eight days after the district court issued its preliminary injunction, the Board's Acting General Counsel Joseph Desio issued a memorandun in which le advised regional offices to take the following steps:

1. If the proposed health care unit does not involve an acutecare hospital, the Region should continue to process these cases. An

162. See id. at 705 n.1.

163. See id. at 716.

164. American Hosp. Ass'n v. NLRB, 899 F.2d 651 (7th Cir. 1990). The opinion was authored by Judge Richard Posner, and joined by Judges Kenneth Ripple and Michael Kanne.

165. See id. at 660 .

166. American Hosp. Ass'n v. NLRB, 111 S. Ct. 242 (1990).

167. American Hosp. Ass'n v. NLRB, 111 S. Ct. 1539 (1991).

168. See supra note 79 and accompanying text. 
acute-care hospital is defined [by] the Final Rule, and excludes facilities that are "primarily nursing hoines, primarily psychiatric hospitals, or primarily rehabilitation hospitals."

2. If the proposed unit involves an acute-care facility, and the unit would be appropriate under St. Francis and St. Vincent the Region should continue to process these cases.

3. If the einployer is an acute-care facility and the petition seeks a separate unit for registered nurses, doctors, skilled maintenance elnployees or business office clericals, i.e., the case would be decided differently under the Final Rule than under St. Vincent, and the Region cannot secure a stipulation as to the urit, please defer processing the petition pending further notice. ${ }^{169}$

Because almost all "delayed" petitions would have fallen into the third category, the Desio memorandum, for all practical purposes, stopped the processing of petitions in covered health care institutions. Thus, the iromic effect of the issuance of the final rule coupled with the issuance of the preliminary mjunction and the Desio memoranduin was to bring to a halt formal organizing activities in acute care hospitals, the most prominent part of the health care industry.

In the proceedings before the district court, the AHA made three arguments: (1) the "in each case" language of section 9(b) of the Act precluded the use of rulenaking to define units; (2) the rule contravened the congressional adinomition against "undue prohferation" in health care units; and (3) the rule was arbitrary, capricious, and was not supported by substantial evidence. ${ }^{170}$ The Board, apart froin opposing the three AHA arguments on the merits, also contended that the district court lacked jurisdiction to review the regulation, either because it (like a Board determination of an appropriate bargaining umit) was not a "final order" within the NLRA scheme ${ }^{171}$ or because the case was not ripe. ${ }^{172}$

On July 25, 1989, the district court issued the perinanent injunction against the rule. 173 After disposing of the Board's jurisdictional objection, ${ }^{174}$ the court rejected the AHA's argument that the "in each case" language entirely foreclosed the Board from rulemaking with respect to

169. Memorandum of NLRB General Counsel No. 89-70 (May 30, 1989) (citations omitted), reprinted in Daily Lab. Rep. (BNA) No. 104, at A-2 (June 1, 1989).

170. See American Hosp. Ass'n v. NLRB, 718 F. Supp. 704, 705 (N.D. Ill. 1989).

171. See id. at 705 n.2. In support of this position, the Board relied upon Boire v. Greyhound Corp., 376 U.S. 473 (1964), Leedom v. Kyne, 358 U.S. 184 (1958), and American Fed'n of Labor v. NLRB, 308 U.S. 401 (1940).

172. See American Hospital, 718 F. Supp. at 705 n.2. In support of this position, the Board rehied upon Abbott Lab. v. Gardner, 387 U.S. 136 (1967), and its progeny.

173. American Hospital, 718 F. Supp. at 716.

174. See id. at 711. The Board abandoned these jurisdictional arguments on appeal. 
unit determinations. Instead, the court held that any rule that designated "an absolute number of appropriate units" for health care institutions was inconsistent with the congressional admonition against undue proliferation. ${ }^{175}$ Having concluded that the rule was unlawful on that ground, the court found it unnecessary to consider the AHA argument that the rule was arbitrary and capricious. ${ }^{176}$

On July 31 , the Board filed its notice of appeal of the district court decision. The Board requested, but was denied, an expedited appeal.177 Although the Board's immediate objective was to overturn promptly the district court decision, there was a further concern. Health care industry representatives suggested that if the district court decision was overturned (or even if the district court had decided in favor of the Board) further actions challenging the rule would be filed in other districts throughout the country. ${ }^{178}$ Because the NLRA does not specify the niethod for judicial review of a Board rule, review could be had by way of an action for declaratory and injunctive relief im virtually any U.S. district court-traditional "non-statutory" review. 179 It was relatively clear, however, that menibers of the AHA would be barred, under the "association representation" branch of the preclusion doctrine, from bringing any such subsequent action. ${ }^{180}$ Yet it was quite unclear whether the numerous hospitals that were not inenibers of the AHA would be barred under the "virtual representation" branch of that doctrine front asserting separate claims challenging the rule. ${ }^{181}$ The uncertainty and confusion that would have been created by successive actions challenging the rule were resolved when the Supreine Court granted certiorari, and

175. See id. at 716.

176. See id. at 716 n.17.

177. The order denying the expedited appeal was entered on August 16, 1989.

178. For example, hospital attorney Roger King stated that "hospitals are entitled to challenge the rules in $\mathbf{4 7}$ other states. 'Until the Supreine Court ultimately passes on the validity of the unit determination rules ... we will proceed in our chents' representation cases in precisely the same way as we have done so in the past." "David Burda, NLRB Prepares to Implement New Hospital Bargaining Rules, MOD. HEALTHCARE, Apr. 23, 1990, at 3.

The AHA relied on this position in its petition for certiorari. See Petition for Certiorari at 2830, American Hosp. Ass'n v. NLRB, 111 S. Ct. 1539 (1991) (No. 90-97).

179. The presumption of reviewability of final agency action, see APA, 5 U.S.C. $\$ \$ 701,702,704$ (1988); Abbott Lab. v. Gardner, 387 U.S. 136, 139-41 (1967), coupled with the availability of broad jurisdictional provisions, see 28 U.S.C. $§ 1331$ (1988) (federal question); id. $\S 1337$ (questions arising under statutes regulating commerce), provide a basis for review of agency rulenaking even where the statutory scheme granting rulenaking authority does not specifically provide for review of final rules.

180. See Western Coal Traffic League v. ICC, 735 F.2d 1408, 1411 (D.C. Cir. 1984); 18 Charles A. Wright et Al., Federal Practice And Procedure § 4456 (1981 \& Supp. 1991).

181. See WRIGHT, supra note $180, \S 4457$. 
the elimination of that prospect was one of the factors that led the Board not to oppose the AHA petition for certiorari. ${ }^{182}$

\section{B. Court of Appeals Proceeding}

The Court of Appeals decision on April 11, 1990 came nearly one year after publication of the final rule. The decision reversed the district court, vacated the injunction, and directed the district court to enter judgment for the Board. ${ }^{183}$ Nevertleless, the court granted the inotion of the AHA to liave its order stayed pending the filing and disposition of the AHA's petition for certiorari. ${ }^{184}$

The opinion, written by Judge Posner, first rejected the argument that the " $\mathrm{m}$ each case" language of 9(b) barred the rule, finding that the terms of 9 (b) taken as a wliole suggested a less restrictive meaning and that the "scant" legislative history of the provision was not imconsistent with sucli an interpretation. ${ }^{185}$ The opinion also rejected the argument that the rule was inconsistent with the so-called "congressional admonition" agamst undue proliferation included in the House and Senate coinmittee reports. ${ }^{186}$ Althougli the court treated the commentary as bona fide legislative history, ${ }^{187}$ it concluded that interpretimg the "admonitions" as equivalent to the failed unit determination provision would give

182. Brief on Petition for Certiorari for the National Labor Relations Board at 15-16, American Hosp. Ass'n v. NLRB, 111 S. Ct. 1539 (1991) (No. 90-97).

183. American Hosp. Ass'n v. NLRB, 899 F.2d 651, 660 (7th Cir. 1990).

184. See Stay Order, May 3, 1990, American Hosp. Ass'n v. NLRB, Nos. 89-2604, 89-2605, and 89-2622 (7th Cir.); see also Seventh Circuit Grants Request to Stay NLRB Bargaining Unit Rule, Daily Lab. Rep. (BNA) No. 88, at A-12 (May 7, 1990); Seventh Circuit Rejects NLRB Motion to Reconsider Stay of Health Care Rules, Daily Lab. Rep. (BNA) No. 104, at A-10 (May 30, 1990).

185. See American Hospital, 899 F.2d at 656. The court recognized several possible interpretations:

The reference in section $9(\mathrm{~b})$ to employer, craft, and plant units suggests that the term "in each case" was included to prevent the Board from bringing about a revolution in unit determinations by prescribing employer units, or craft units, or plant units for all einployers under the Board's jurisdiction. ... But it is consistent with the background and semantics of the proviso that a "case" can be an imdustry or (as here) a subset or submarket of an industry; it need not be a particular dispute between a particular employer and a particular union at a particular plant or establishment.

Another possibility is that "in each case" sunply expresses the truisin that, whether or not the Board proceeds by formal rulemaking, it still must determine the bargaining units in each case in which there is a dispute over how to classify particular workers. In other words, a rule, like a statute, is apphed case-by-case. Still another possibility is that "case" means "proceding" in a sense broad enough to cover a ruleınaking proceeding as well as an adjudicative one.

Id. (citations omitted).

186. For a discussion of the judicial interpretation of this inandate, see supra text accompanying notes 59-71.

187. The court rcasoned:

Ordinarily a committee report that is not explaining new or altered statutory language has hitle significance in the interpretation of a statute. . . Congress legislates by passing bills and sending them to the President for his signature. It does not legislate by issuing 
the imdustry "something it tried and failed to win from Congress." 188 Finally, the opinion rejected the AHA argument that the rule was arbitrary and capricious because it treated identically hospitals of different sizes and missions in different locations. ${ }^{189}$

Thus, although the Board prevailed on all three issues before the court of appeals, the court's subsequent stay order left the Board with a rule that was still unenforceable. Under the terms of the order, vacation of the injunction was stayed pending disposition of the case im the Supreme Court. ${ }^{190}$

committee reports. Post-enactment legislative history . . . is sometimes a sneaky device for trying to influence the interpretation of a statute, in derogation of the deal struck in the statute itself among the various interests represented in the legislature. ...

....

The admonition in the 1974 committee reports is certainly not a statute, and courts that liave treated it as such liave in our view erred. ... The admonition lies between the polar cases of a committee report that does not accompany legislative action and a committee report that explains a newly enacted or amended statute, but is we think closer to the latter. ... The admorition can therefore be regarded as a commentary on the ineaning of the 1974 amendments and hence as equivalent to pre-enactment legislative history, rather than as a gratuitous comment unrelated to legislative action ....

American Hospital, 899 F.2d at 657-58.

188. The court explaimed:

[T] he fact that the liospital industry would lave dearly loved to amend the unit-determination provision yet failed to do so inust give us pause in treating the "admonition" as if it were a statute, which anyway it plainly is not. To treat it as one would give the hospital industry something it tried and failed to win from Congress. Moreover the admomition does not read like a statute. It is cautionary rather than directive. ... [S] uch an expression is entitled to our respectful cousideration, not ouly for its intrinsic inerits but also for what light it slieds on Congress's intentions in the 1974 amendments. But it is not an amendment to seetion $9(\mathrm{~b})$, deereeing that in the liealth-care industry no more than three separate bargaining units shall be authorized.

Id. at 658 (citations omitted).

189. The court explained:

The lumping together of all acute-care lospitals into one category for purposes of prescribing proper bargaining units does of course overlook a great deal of relevant diversity. What the loospital industry refuses to acknowledge is that this is the very nature of rules. A rule inakes one or a few of a mass of particulars legally deeisive, ignoring the rest. The result is a gain in certainty, predictability, celerity, and econony, and a loss in individualized justice. Often the tradeoff is worthwhile; at least the prevalence of rules in our legal systein so suggests. The lospital industry is acutely conscious of the costs of rules, but disregards the benefits. ...

For its first forty-four years the Board tried to channel its discretion over unit determination in common law fashion, proposing and inodifying standards case-by-case. That was the approach it took when the nonprofit liealth care sector was brought under its aegis in 1974. The approach is widely regarded as a failure .... Against this dismal background it was not unreasonable for the Board to experiment with substituting a tight rule for a loose standard. . . . It gave plausible rcasons for its cloice.

....

... It is not for us to fine-tune the regulatory process by telling the Labor Board that its rule slould make slightly more distinctions than it does, or slightly fewer. The Board did a responsible job of weighing the conflicting arguments, and we therefore upliold its rule witliout pretending that we consider it Utopia.

Id. at 659-60.

190. See supra text aecompanying note 165 . 


\section{Supreme Court Proceeding}

The brief of the AHA in the Supreine Court ${ }^{191}$ maintained all three formal arguments that had been made in the courts below, but focused on two themes that cut across the three arguments. First, the brief emphasized the "rigidity" of the rule in the face of "diversity" in the health care industry and in light of the congressional non-proliferation admomtion. ${ }^{192}$ Thus, ratlier than broadly attacking the legal authority of the Board to use rulemaking, or even its authority to use rulemaking im some fashion for unit issues, the brief argued that the outcome-determinative character of this particular rule precluded the Board from considering individual case differences as required by the " $\mathrm{m}$ each case" language. Second, the brief urged that the use of rulemaking for health care unit determinations, as well the rule itself, represented an abrupt and insufficiently explained departure from prior Board policy. ${ }^{193}$ This theme drew not ouly upon the Board's commitment to the adjudicative approach in its prior health care unit decisions, but also upon its prior statenients concerning diversity im the health care industry as it affected unit determinations and prior Board decisions arguably mconsistent with the substance of the rule.

The broad theme of the Board's response to the AHA arguments echoed Judge Posner's conclusion: The rule warranted judicial respect as the careful and sensible product of a public process that would enable the agency to function more fairly and efficiently by narrowing and defining the scope of issues that must be adjudicated. ${ }^{194}$ The Board's brief maintained that the "in each case" language simply ensured that individualized proceedings would be available for the application of any rules (whether formulated in a rulemaking or an adjudication) that were relevant in a particular case. ${ }^{195}$ The brief defended the health care unit rule, and the proceeding underlying it, as fully reflecting a "due consideration" of the congressional admomition on the issue of bargaining unit proliferation and as fully explaining any departure from prior policy. ${ }^{196}$

In oral argument, the AHA exclusively concentrated on the import of the "in each case" language. ${ }^{197}$ It asserted that the rule left nothing for the Board to determine "im each case," because even the exception for

191. Brief for the American Hospital Association, American Hosp. Ass'n v. NLRB, 111 S. Ct. 1539 (1991) (No. 90-97).

192. See id. at 39.

193. See id. at $40-41$.

194. Brief for the National Labor Relations Board at 14-16, American Hospital (No. 90-97).

195. See id. at 16-17.

196. See id. at 32-33.

197. See Hospital Industry Urges Court to Rule That NLRB Health Care Rule Violates Act, Daily Lab. Rep. (BNA) No. 38, at A-5 (Feb. 26, 1991). 
"extraordinary circumstances" was so narrowly drawn as to be "illusory."198 Questioning from the Court required counsel for the AHA to distinguish between this use of rulemaking and other widely accepted uses of rulenaking that limit hearing rights, mcluding "rules" formulated by the Board im adjudications. ${ }^{199}$ Although AHA counsel sought to differentiate the health care unit rule by arguing that other rules left inore room for case-by-case determination, ${ }^{200}$ at bottom the AHA position was that the " $m$ each case" language of the Act uniquely limited the power of the Board to make outcoine-determinative rules on umit questions.

In response, the Board argued not only that the critical statutory language was not a substantive limit on its rulemaking authority, but also that even in processing petitions under the health care rule it would be necessary to make individualized determinations, most obviously that the petitioned-against party was in fact an "acute care hospital."201 Counsel for the Board did not, however, atteinpt to argue that the rule satisfied the "in each case" language merely because it provided an exception for "unusual circumstances." Instead, counsel essentially conceded the narrowness of the exception, and, in response to a question froin the Court, asserted that the rule would be valid even without the exception. ${ }^{202}$ Board counsel also addressed the "congressional admomition" and "arbitrary and capricious" arguments that the AHA had raised in its brief but had not pursued in oral argument. ${ }^{203}$

On April 23, 1991, less than two months after oral argument, a unanimous Court, speaking through Justice Stevens, affirmed the Seventh Circuit. ${ }^{204}$ In upholding the validity of the rule, the Court reasoned that the Board's general rulemaking authority "was unquestionably sufficient to authorize the rule .. . unless limited by some other provision im the Act."20s Turning to the "in each case" language, the Court rejected the AHA reading of the provision as such a limit:

Although the contours of the restriction that petitioner ascribes to the phrase are murky, petitioner's reading of the language would prevent the Board from imposing any industry-wide rule delineating the appropriate bargaining units....

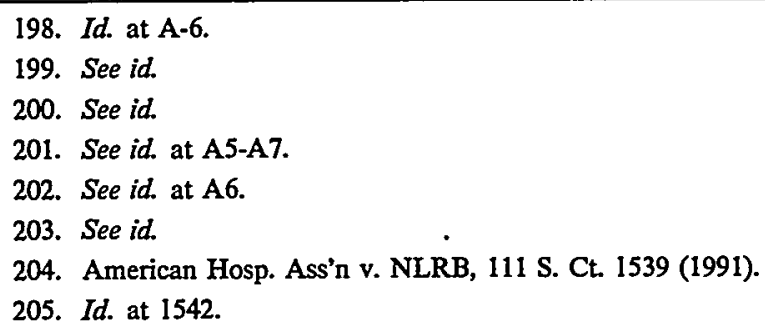


The more natural reading of these three words is simply to indicate that whenever there is a disagreement about the appropriateness of a unit, the Board shall resolve the dispute. Under this reading, the words "in each case" are synonymous with "whenever necessary" or "im any case in which there is a dispute." ...

In resolving such a dispute, the Board's decision is presumably to be guided not simply by the basic poticy of the Act but also by the rules that the Board develops to circuniscribe and to guide its discretion either in the process of case-by-case adjudication or by the exercise of its ruleinaking authority. ${ }^{206}$

The Court further found that the "structure and policy" of the Act, as well as the legislative history of the unit determination provision, "reinforced" this view of the statutory language. ${ }^{207}$ Had the term "in each case" been intended to limit the broad section 6 ruleniaking authority of the Board, the Court reasoned, Congress would have been "expected to do so in language expressly describing an exception from that section or at least referring specifically to the section."208 Likewise, if the provision "had been intended to place an important limitation on the scope of the Board's ruleniaking powers," the legislative history would have been expeeted to contain "some expression of that intent."209 Citing Chevron U.S.A., Inc. v. Natural Resources Defense Councih, Inc., ${ }^{210}$ the Court concluded by observing: "Even if we could find any ambiguity in $\S 9(\mathrm{~b})$ after

206. Id. at 1542-43. As had the Board, the Court quoted Professor Davis's conclusion that the statutory language "does not prevent the Board from supplanting the original discretionary chaos with some degree of order." See supra note 96 and accompanying text. The Court continued:

This reading of the "in each case" requirement comports with our past interpretations of similar provisions in other regulatory statutes. These decisions confirm that, even if a statutory schene requires individualized determinations, the decisionmaker has the authority to rely on rulemaking to resolve certain issues of general applicability unless Congress clearly expresses an intent to withhold that authority.

Even petitioner acknowledges that "the Board could adopt rules establishing general principles to guide the required case-by-case bargaining unit determinations." Petitioner further acknowledges that the Board has created many such rules in the half-century during which it has adjudicated bargaining unit disputes. Petitioner contends, however, that a rule delineating the appropriate bargaining unit for an entire industry is qualitatively different froin these prior rules, which at inost established rebuttable presumptions that certain units would be considered appropriate in certain circuinstances.

We simply cannot find in the three words "in each case" any basis for the fine distinction that petitioner would have us draw. Contrary to petitioner's contention, the Board's rule is not an irrebuttable presnmption; instead, it contains an exception for "extraordinary circumstances." Even if the rule did estabtish an irrebuttable presnmption, it would not differ significantly from the prior rules adopted by the Board. As with its prior rules, the Board must still apply the rule "in each case." For example, the Board must decide in each case, among a host of other issues, whether a given facility is properly classified as an acute eare hospital and whether particular employees are properly placed in particular units.

American Hospital, $111 \mathrm{~S}$. Ct. at 1543 (citations onitted).

207. See American Hospital, 111 S. Ct. at 1543.

208. Id.

209. Id. at 1544.

210. 467 U.S. 837 (1984). 
employing the traditional tools of statutory construction, we would still defer to the Board's reasonable interpretation of the statutory text."211

The Court also rejected the various forms of the AHA argument that the congressional admomition created a judicially enforceable standard for Board health care units determinations. It read the admonition as:

a form of notice to the Board that if it did not give appropriate consideration to the problem of proliferation in this industry, Congress might respond with a legislative remedy. . . . If Congress behieves that the Board has not given "due consideration" to the issue, Congress may fashion an appropriate response. ${ }^{212}$

Finally, the court rejected the AHA argument that the rule was arbitrary and capricious because it ignored "critical differences among the 1nore than 4,000 acute-care hospitals in the United States":213

Given the extensive notice and comment rulemaking conducted by the Board, its careful analysis of the comments that it received, and its well-reasoned justification for the new rule, we would not be troubled even if there were imconsistencies between the current rule and prior NLRB pronouncements. The [statute] . . contemplates the possibility that the Board will reshape its policies on the basis of more information and experience in the administration of the Act. The question whether the Board has changed its view about certain issues or certain industries does not undermine the validity of a rule that is based on substantial evidence and supported by a "reasoned analysis." 14

The Court further held that "[ $t]$ he fact that petitioner can point to a hypothetical case in which the rule might lead to an arbitrary result does not render the rule "arbitrary or capricious." "215 The Court reasoned that it was "likely" that if the Board was presented with a case to which its application of the rule would be arbitrary, "the Board would conclude that 'extraordinary circumstances' justified a departure froin the rule. ${ }^{216}$

211. American Hospital, $111 \mathrm{~S}$. Ct. at 1544.

212. Id. at 1545-46 (citation omitted).

213. Id. at 1546 .

214. Id.

215. Id. at 1547 .

216. Id. (citation omitted). The Court noted, however, that even if "the Board might dechine to do so, we cannot conclude the entire rule is invalid on its face." Id.

Addressing the Board's attention in the rulemaking to the issue of diversity in the health care industry, the Court observed:

The Board's conclusion that, absent extraordinary circumstances, "acute care hospitals do not differ in substantial, significant ways relating to the appropriateness of units," was based on a "reasoned analysis" of an extensive record. The Board explained that diversity among hospitals had not previously affected the results of bargaining unit determinations and that diversification did not inake rulemaking inappropriate. The Board justified its selection of the individual bargaining units by detailing the factors that supported generalizations as to the appropriateness of those units.

Id. at $1546-47$ (citations omitted). 
By rejecting all three arguments of the AHA, the Court not only put to rest the question of the validity of the health care unit rule, but also authoritatively resolved the significance of the congressional adnuonition with respect to proliferation of health care units and the power of the Board to use ruleinaking generally and for unit issues particularly.

\section{EVAluation and Recommendations}

Any evaluation of these events inust begin with the observation that the first inajor substantive use of rulemaking by the Board is, without more, a inatter of some significance for both administrative practice generally, and national labor policy particularly. Symbolically, a barrier has fallen. An agency that for inore than fifty years abjured a policynuaking technique that is one of the hallmarks of American administrative practice has shed its curmudgeonly procedural image. Labor pohicy, if only in a single instance, has been influenced by the form and character of public participation that notice and comment rulemaking provides. Yet does this historic event mark a turning point in Board policy and practice? This question is divided into several sub-questions below. Some tentative (and admittedly soinewhat speculative) answers are offered.

\section{A. Why Now?}

First, to what extent was the Board's willingness to pursue a new policyinaking technique influenced by the particularly difficult policy dilemma it faced after a thirteen-year struggle with the Health Care Amendments and the decision of the D.C. Circuit in St. Francis II? Clearly, this was an important factor. Any prospect for a fresh approach would have seemed attractive. Although seeking Supreme Court review in an adjudication was certainly a possibility, that approach would have bound the Board to defending a pohicy about which soine members may have had lingering doubts and would, given the mixed results in the circuits and subtle distinctions in a number of Board decisions, have risked surrendering to the Supreine Court some relatively inuportant pohicy choices. Nevertheless, this was not the only difficult policy issue facing the Board in mid-1987 and, given the controversy it had generated, the issue of health care unit determinations was an especially conplex and risky problein on which to experiment with an untried policymaking device.

What else, then, may have influenced the Board to proceed by rulemaking? Beginning in the early 1980s, labor leaders became increasingly vocal and direct in their criticisin of evolving Board policy that 
they perceived to be hostile to unions. ${ }^{217}$ By the time the health care rulemaking was begun, labor had demonstrated its displeasure with Board policy under some circunistances by avoiding use of its processes. ${ }^{218}$ Board caseload, as well as Board credibility with an important part of its regulated constituency, was thus affected. Although rulemaking posed the risk for unions of locking in unfavorable policy, it also offered the prospect of reducing delays in accomplishing representation by limiting the opportumities for litigation. It is thus possible that the Board decision to undertake rulemaking was intended, in part, by some members as an invitation to an estranged constituency to return to the regulatory process. ${ }^{219}$

Most likely botli the pressing need for a clean solution to the liealth care unit issue and a desire to improve relations with labor influenced the Board. But the factor that may ultimately have tipped the balance in favor of a decision to proceed witl rulemaking was staff imitiative. In 1981, the Director of the Office of Representation Appeals, Berton Subrin, liad written an article suggesting the desirability of using rulemaking to resolve umit issues.220 At the point the Board was forced to confront St. Francis $I I$ on remand, Subrin was presunrably still persuaded of the utility of rulemaking and was in the position to convey his views to the Board. 221

If the coincidence of these three factors led to the initiation of the rulemaking, will further Board rulemaking require a similarly compelling set of circumstances? Perliaps, but the fact that the process has now been used eliminates a significant aspect of the mertia that serves to inhibit agency experimentation of this sort. A far more important factor bearing on the likelihood of further Board rulemaking will be the implicit costbenefit analysis that botlı members and staff will undertake as the rule is put into effect.

217. For example, in 1984, AFL-CIO President Lane Kirkland asserted that, given the way the NLRA was being enforced, organized labor would be better off if the Act were repealed. See Cathy Trost \& Leonard M. Apcar, AFL-CIO Chief Calls Labor Laws a 'Dead Letter', WALL. ST. J., Aug. 16,1984 , at 8 .

218. For example, William Wynn, President of the United Food and Commercial Workers of America, indicated in 1984 that his union would boycott the Board. See Has Labor Law Failed?: Joint Oversight Hearings Before the Subcomm. on Labor Management Relations of the Senate Comm. on Education and Labor and Manpower and the Subcomm. on Housing of the House Comm on Government Operations, 98th Cong., 2d Sess. 57-60 (1984).

219. See supra notes 121-23 and accompanying text.

220. See Subrin, supra note 3.

221. In fact, Subrin participated in the two open meetings of the Board held prior to the issuance of the notice of proposed rulemaking. See Transcript of Meetings of May 15, 1987 and June 9, 1987. 


\section{B. Did It Work?}

Undoubtedly, an important element in this cost-benefit analysis is the positive reaction of the Supreme Court to the Board's initiative. Both symbolically and practically, an adverse Supreme Court decision would have been devastating for the forces within the Board that inight stimulate further use of rulemaking. The breadth and clarity of the Supreme Court's approval of the rule suggests a strong, if inexplicit, endorsement of rulemaking as a useful policymaking vehicle.222

An equally important element is also a particularly speculative one: Will the rule in fact reduce hitigation and delay in representation proceedings? Until the rule is allowed to operate for a period, this question cannot be answered rehably. Nevertheless, the prognosis for the rule seems good. The terms of the rule are clear and straightforward. The rule establishes appropriate umits; it does not merely set standards for units or presunie certain units to be appropriate. Although the rule has an "extraordmary circunistances" exception, the Board has made clear that it intends to construe this provision narrowly, and that the process for testing out the applicability of the exception to particular cases will not in itself be delay-mducing. ${ }^{223}$ The most likely problein would be a

222. Although the opinion contains no explicit praise for the Board's turn to rulemaking for policy formulation nor encouragement to continue in that direction, the Court's unequivocal validation of the rule, despite industry arguments of critical economic implications, conveys respect for the effort to resolve a difficult policy issue through a previously avoided policymaking device. The closing paragraph of the opinion, while separating the Court from the substance of the policy, recoguizes the authority of the Board to make such pohicy choices through rulemaking:

In this opinion, we have defiberately avoided any extended comment on the wisdom of the rule, the propriety of the specific unit determinations, or the importance of avoiding work stoppages in acute care hospitals. We have pretermitted such discussion not because these inatters are unimportant but because they primarily concern the Board's exercise of its authority rather than the limited scope of our review of the legal arguments presented by petitioner. Because we find no inerit in any of these legal arguments, the judgment of the Court of Appeals is affirmed.

American Hospital, 111 S. Ct. at 1547.

223. In NPR II, the Board explained:

To satisfy the requirement of "extraordimary circumstances," a party would have to bear the "heavy burden" to demonstrate that "its arguments are substantially different from those which lave been carefully considered at the rulemaking proceeding," as, for instance, by showing the existence of such unusual and unforeseen deviations from the range of circumstances revealed at the hearings and known to the Board from more than 13 years of adjudicating cases in this field, that it would be unjust or an abuse of discretion for the Board to apply the rules to the facility involved.

The Board, contrary to some industry representatives ...., anticipates that litigation under the "extraordinary circumstances" exception will be rare; the AHA, representing the largest group of health care employers in this proceeding, has indicated it understands that the Board intends to limit exceptions to "truly extraordmary situations," and neither tlie AHA nor any other employer (or union) representative has raised objections to the Board's stated intent.

In unost instances, slould a facility claim it coines within the "extraordinary circumstances" exception, it should present an offer of proof to the Hearing Officer, who will tlien either permit the requested evidence to be addueed or, we anticipate far inore commonly, 
shift in the focus of manageinent litigation from questions of the appropriateness of particular units to questions of "placement" of employees in concededly appropriate units, i.e., in which units do enıployees performing a particular set of duties belong? At least witli respect to acute care hospitals, the Board apparently believes these are manageable issues and seems prepared to respond to attempts to upset the rule's implementation witl such tactics. 224

Assuming the rule can be efficiently impleinented, the cliallenge then becomes determining the costs to the Board in promulgating the rule. Almost two years elapsed between the time when the Board decided to engage in rulemaking and when it issued the final rule. During this period, substantial staff time, mcluding a significant amount of higlilevel staff time, was used to manage the rulenraking and to assist in the analysis of the product of the liearings and comment periods. The novelty of the proceeding for the Board nreant that sonie of this time was spent developing new procedural expertise, but a large part of the time was devoted to dealing witli the hearing and comment process, with a large rulemaking record, and with relatively complex substantive issues. Not only was the time commitment significant as an absolute matter, but also because regular staff ratlier than special rulemaking staff was used, this staff time was thus invested at a cost to other matters. Nevertlieless, efficient implementation of the rule sloould lead to offsetting staff time savings througli straiglitforward application of the rule for unit determinations ratler than staff involvement in the previously required litigation.

Moreover, a portion of the two years was consumed with a procedure not required for notice and comment rulenraking-nulti-location learings witl an opportunity for a form of cross-examination. The possible Board rationales for using such liearings and tlie burdens and benefits of the hearings liave been previously noted. ${ }^{225}$ Under the circunistances of this rulemaking, particnlarly its novelty for the Board, the learings were probably a desirable clioice. Certainly as a legal matter, lowever, and perliaps as a practical matter, the liearings were procedural overkill and tlie burdens created by the number and structure of the liearings

refer the offer to the Regional Director, and, if requested, ultimately to the Board, for ruling.

NPR II, 53 Fed. Reg. 33,900, 33,932-33 (1988) (citations omitted).

224. See id. at 33,932 ("[O]ur intent is to construe the extraordinary circumstances exception narrowly, so it does not provide an excuse, opportunity, or 'loophole' for redundant or unnecessary hitigation and the concomitant delay that would ensue.").

225. See supra text accompanying notes 104-25. 
would have to be considered as part of the overall cost-benefit evaluation of the rulemaking.

Fimally, the post-issuance litigation challenging the rule and the effect of that litigation on implementation of the rule is a necessary part of the evaluation. As noted earlier, in St. Vincent the Board decided that during the pendency of the rulemaking, the prior standards for unit determinations would apply so that petitions could continue to be processed. Apart from the strategic withholding of petitions by unions that anticipated inore favorable opportunities after the issuance of a rule, the busmess-as-usual approach was reasonable and had no furtlier cost. But clearly the Board anticipated that as soon as the rule became effective, it would be implemented. When the district court enjomed enforceinent of the rule, the Board faced a new cost. It effectively chose to suspend processing liealth care petitions ratler than to attempt to defend possibly inconsistent positions: the old versus the new standards. The consequence was tliat for a period of almost two years few acute care hospital petitions were processed. It inust be recoginzed, lowever, that Supreine Court review was responsible for a substantial portion of the delay and would not likely be a part of future rulemakings. Nevertleeless, in this case, the rulemaking and judicial review consumed over three and one half years and liave had an effect on the normal representation process at the Board. Furtliermore, the prospect of successive challenges to the rule througliout the country looined as an additional barrier to iinplementation of the rule and was put to rest only after the Supreme Court granted the petition for certiorari. 226

\section{What Was Learned?}

Putting aside the yet unknowable effects that the rule will liave as it is implemented, it seems clear the proceeding accoinplished the major putative purposes of rulemaking. First, the Board accumulated an enorinous volume of empirical data that simply had not been available to it in adjudications; it thoroughly digested that information and used it effectively in formulating the final rule. Second, the process provided a degree of openness and broad-scale participation simply unmatched by even the most open traditional Board proceedings-oral arguments witl representative amici. Third, the product of the rulemaking is a model of clarity as expression of policy in an area that liad historically been consumed by excessive subtlety and complexity. Finally, the rule promises a

226. The Supreme Court decision in this case, of course, only resolves the validity of this particular rule; any further rulemaking wonld remain subject to the same prospect for delay. 
degree of stability for a policy area that had been overwhelmed by change. In sliort, tlie case can be made, paraphrasing the words of Professor Morris, that the "old Board lias learned a new trick."227

\section{Recommendations}

Faced with a difficult and lingering policy question, the Board boldly chose to experiment witl a policymaking device previously untried in the agency. It cannot be said, however, that tlie clioice represented a broad new commitment to formulating national labor policy through rulemaking. This rulemaking was an exercise in pragmatism-a thorough, careful, and productive admmistrative response to a particular set of circumstances. Nevertlieless, the rulemaking gives the Board experience upon which it can build. Mucli depends upon the success of the rule in accomphishing in representation proceedings the objectives the Board souglit through rulemaking. Yet even as the record develops on the inplementation of the rule, there are steps that could be taken that may enhance the prospects for furtlier rulemaking. ${ }^{228}$

The most formal of tliese steps would be to amend the NLRA to provide specifically for preenforcement judicial review of a final Board rule. This would confine review to a single proceeding, thus avoiding the confusion and inefficiency of serial cliallenges to a rule. The sinnplest and most traditional provision along this lime would authorize an exclusive proceeding in any one of the courts of appeals. ${ }^{229}$ Consistent witl wellrecognized needs for proinpt and comprehensive review when rules having broad national impact are cliallenged, the provision should also impose a tinne limit on seeking preenforcement review, and sliould preclude review in enforcement proceedings of questions of (1) whetler the rule was within the autlority of the Board, (2) wlietlier procedural requireinents for the rulemaking were satisfied, and (3) whetler there was adequate support for the rule in the rulemaking record. ${ }^{230}$

227. See Morris, supra note 3, at 9 .

228. These measures must be coupled with a willingness on the part of at least a majority of the Board to use rulemaking. Three members of the current Board (Chairman Stephens and Members Cracraft and Devaney) supported the health care unit rulemaking. The position of the other two current nembers (Oviatt and Raudabaugh) on the use of rulemaking is not a matter of record.

229. See The Choice of Forum for Judicial Review of Administrative Action (Recommendation No. 75-3), 1 C.F.R. § 305.75-3 (1991).

230. See Judicial Review in Enforcentent Proceedings (Recomnendation No. 82-7), 1 C.F.R. $\S$ 305.82-7 (1991); see also Paul R. Verkuil, Congressional Limitations on Judicial Review of Rules, 57 TUL. L. REv. 733 (1983) (discussing the extent to which Congress should limit judicial review of agency rules). 
Although there is no apparent need to amend the NLRA to provide a more detailed procedure for rulemaking than is provided by section 553 of the APA, ${ }^{231}$ it would be desirable for the Board to develop a standard set of rulemaking procedures that would be in place and understood should another proceedimg be undertaken. In formulating such procedures, the Board should consider whether the hearing component of the health-care unit rulemaking yielded a form of participation and data that should be carried forward into future rulemakings or whether written comments and data would suffice. ${ }^{232}$ Given the burdens the hearings imposed, and recognizing the procedural variations available even in a written comment process, there appears to be little reason for the Board to hold such hearings as a matter of course.

Similarly, it is possible that further use of rulemaking would be a more reahistic prospect for the Board, as an institutional matter, if there were a staff that could be called upon to provide support regardless of the particular subject of the rulemaking. Such a staff not only might provide support in ongoing proceedings, but also might be a source of substantive and procedural expertise in considering future rulemakings.

A regularized method for identifying manageable and timely subjects for possible rulemaking could also facilitate this form of policymaking. The body of law represented by the cases adjudicated over the fiftyfive year history of the Board is enormous and complex. Any notion that this entire body of law, or even any substantial part of it, can be reduced to useful rules through the rulemaking process is simply unrealistic. Yet by combining a rulemaking staff with an interual process for identifying and evaluating potential subjects for rulemaking, the Board could inform itself more fully of the consequences of the procedural choices it inevitably makes when it consciously engages in policymaking.

Factors that should influence the selection of furtlier subjects for rulemaking mclude not only the considerations traditionally posited in coimection with agency choice between rulemaking and adjudication, 233 but also considerations unique to the Board's imstitutional structure and enforcement responsibilities. ${ }^{234}$ Even where the choices for rulemaking. seem obvious, as in the case of health care units, or perhaps in a new area of Board law, such as regulating the range of activities for which a union

231. See S U.S.C. $\$ 553$ (1988) (requiring the agency to provide notice of the rulemaking proceedings, an opportunity for meaningful participation by interested persons, and publication of a substantive rule within 30 days).

232. See Procedures in Addition to Notice and the Opportunity for Comment in Informal Ruleınaking (Recommendation No. 76-3), 1 C.F.R. § 305.76-3 (1990).

233. See, e.g., Berg, supra uote 10; Shapiro, supra note 3.

234. See supra note 33 and accompanying text. 
may expend dues and fees collected pursuant to union security provisions, ${ }^{235}$ something might be gained by preliminary staff investigation and analysis. This function could perhaps be performed adequately within existing staffs, but for purposes of obtaining a meaningful overview of rulemaking prospects, a staff with no fixed substantive domain niay offer an advantage.

Finally, in any instance in which the possible subject for ruleınaking is one treated by existing Board law (as opposed to an entirely new subject), the Board faces a difficult choice if enforcement of the rule is enjoined during the review process. The Board will have committed itself to a position that may be inconsistent with its prior position, but one which it is then barred from implementing. Using the prior position and defending its use is difficult, but suspending action in an area pending final determination on a newly promulgated rule has its costs as well. Although the effect of this scenario could vary depending on the particular rule at issue, and might also be offset by a single statutorily prescribed review proceeding as suggested above, ${ }^{236}$ it is a inatter about which the Board should formulate a general policy. Given its broad enforcement responsibilities, the Board should ordinarily continue to apply existing law during the pendency of a rulemaking as it did with health care unit determinations. Yet once a rule is promulgated, even though it inay become the subject of judicial review, the Board should ordinarily apply the law expressed in the rule as proinulgated-unless a court order issued in the course of the review proceeding would preclude that action. Although unusual circumstances may require departure from this approach, adherence to existing law during rulemaking followed by prompt implementation of any newly adopted rules is consistent both with the concept of prospective pohicymaking through the consideration and promulgation of rules and with the responsibility of the Board to provide ongoing enforcement of the NLRA.

\section{CONCLUSION}

Adoption of the ineasures recommended here will only facilitate the use of rulemaking by the Board, not ensure greater use. Short of legislatively mandated rulemaking, the likelihood of further Board rulemakings ultimately depends upon a judgment that this policymaking device meaningfully contributes to the effectuation of the purposes of the NLRA, as

235. See Communications Workers of Am. v. Beck, 487 U.S. 735 (1988).

236. See supra text accompanying notes 231-32. 
those purposes are understood by individual Board meinbers. The health care umit rulemaking and its aftermath will provide critical data as that issue is considered. Perhaps most importantly, it will serve to move discussion from the abstract to the concrete. 